
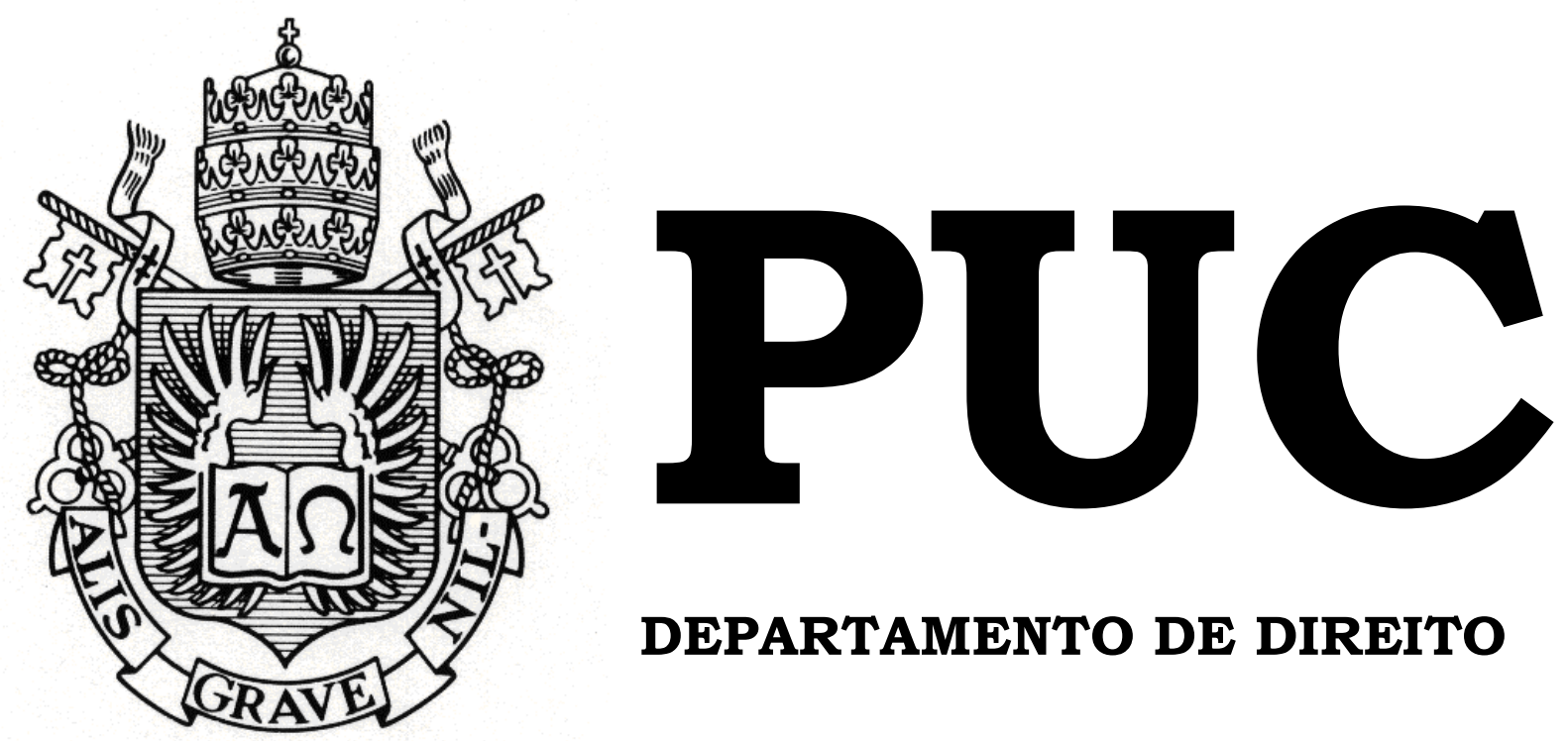

DEPARTAMENTO DE DIREITO

\title{
ASPECTOS GERAIS DA CONVENÇÃO DE HAIA DE 1980 SOBRE SEQUESTRO INTERNACIONAL DE MENORES
}

Por

Maísa Sampietro Pinheiro

ORIENTADORA: Nádia de Araujo

2015.2

PONTIFÍCIA UNIVERSIDADE CATÓLICA DO RIO DE JANEIRO RUA MARQUÊS DE SÃO VICENTE, 225 - CEP 22453-900 RIO DE JANEIRO - BRASIL 


\title{
ASPECTOS GERAIS DA CONVENÇÃO DE HAIA DE 1980 SOBRE SEQUESTRO INTERNACIONAL DE MENORES
}

\author{
por \\ Maisa Sampietro Pinheiro
}

Monografia apresentada ao Departamento de Direito da Pontificia Universidade Católica do Rio de Janeiro (PUC-Rio) para a obtenção do Título de Bacharel em Direito.

Orientadora: Nádia de Araujo 


\section{AGRADECIMENTOS}

Agradeço, primeiramente, à minha família, pois não existe quem resista às tempestades sem um porto-seguro para acalmar as incertezas e acalentar a alma.

Aos meus amigos, amigas e companheiros de faculdade, esta jornada não seria nem bela, nem inspiradora, sem a presença de cada um de vocês me escoltando o caminhar.

Não poderia deixar de agradecer à minha orientadora Nádia, por todo o aprendizado que ultrapassa as singelas páginas desta monografia e pelo apoio acadêmico imprescindível para minha construção como profissional. 


\section{RESUMO}

Este trabalho traz uma análise da Convenção de Haia de 1980 sobre Sequestro Internacional de Menores, mais especificamente das exceções de retorno contidas no Artigo 13, alínea b, a respeito das indeterminações e questionamentos contidos na mesma, além da problemática da violência doméstica em situações de subtração, seguido, enfim, por um estudo de jurisprudências estrangeiras e casos brasileiros dentro do tema em questão.

\section{PALAVRAS-CHAVE}

Direito Internacional Privado - Convenção de Haia de 1980 - Sequestro Internacional de Menores - Exceções à obrigação de retorno - Cooperação Jurídica Internacional - Direitos Humanos - Violência Doméstica 


\section{SUMÁRIO}

INTRODUÇÃ̃O

CAPítulo 1 - A Convenção de Haia de 1980 sobre Sequestro

Internacional de Menores.............................................8

1.1. O contexto global da Convenção de Haia.............................8

1.2. A Convenção no Brasil.............................................16

CAPÍTULO 2 - Exceções à obrigação de retorno........................26

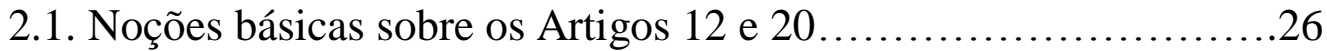

2.2. O Artigo 13 da Convenção........................................29

CAPÍTulO 3 - O Artigo 13, alínea b, da Convenção....................33

3.1. Risco grave de perigos de ordem física e psíquica e situação

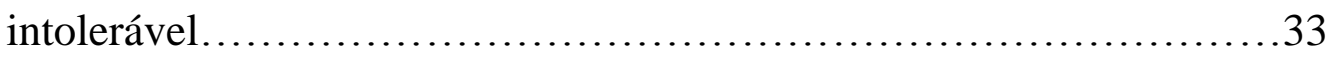

3.2. A problemática da violência doméstica nos casos de subtração internacional de menores........................................... 37

3.3. Análise de jurisprudência........................................42

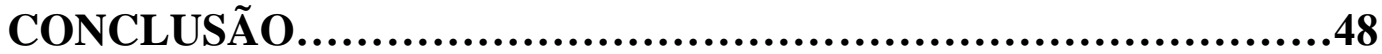

REFERÊNCIAS BIBLIOGRÁFICAS..............................51 


\section{LISTA DE ABREVIAÇÕES}

AGU - Advocacia Geral da União

STJ - Superior Tribunal de Justiça

STF - Supremo Tribunal Federal

TRF - Tribunal Regional Federal

SPM - Secretaria de Políticas para as Mulheres

ACAF - Autoridade Central da Administração Federal

SDH/PR - Secretaria de Direitos Humanos da Presidência da República

Explanatory Report - Relatório Explicativo

Taking Parent - Genitor abdutor 


\section{INTRODUÇÃO}

Com o mundo se tornando cada vez mais diversificado, complexo, possibilitando a constante circulação de pessoas e a troca de bens e serviços, temos o surgimento de inúmeros conflitos que transcendem as barreiras territoriais.

Logo, na seara jurídica, um ordenamento jurídico deve ser capaz de acompanhar e se adaptar às novas realidades sociais, sejam elas de caráter interno ou plurinacionais, a fim de dirimir os litígios emergentes decorrentes da evolução de uma coletividade heterogênea.

Essa necessidade proporcionou, dentre outros efeitos, uma expansão qualitativa e quantitativa ${ }^{1}$ do Direito Internacional, nos âmbitos privado e público, perpetuando-se como instrumento de regência social, agora em conjunto com o ordenamento nacional, que até então era visto como única matriz capaz de gerir a vida em sociedade.

Esta busca por uniformidade resultou no fenômeno denominado de "pluralismo de ordens jurídicas", devido à mescla das regras que regulam a sociedade internacional ${ }^{3}$ com as diferentes áreas do direito interno

\footnotetext{
${ }^{1}$ RAMOS, André de Carvalho. Artigo Pluralidade Das Ordens Jurídicas: Uma Nova Perspectiva Na Relação Entre O Direito Internacional E O Direito Constitucional, em Revista da Faculdade de Direito da Universidade de São Paulo, v. 106/107, p. 500

${ }^{2}$ Segundo o doutrinador André Ramos, o pluralismo de ordens jurídicas consiste na "coexistência de normas e decisões de diferentes matrizes com ambição de regência do mesmo espaço social, gerando uma série de consequências relacionadas à convergência ou divergência de sentidos entre as normas e decisões de origens distintas. As ordens jurídicas plurais, então, são aquelas que convergem e concorrem na regência jurídica de um mesmo espaço (a sociedade nacional)". Ibid. p. 500.

${ }^{3}$ Esta nova ordem decorrente fenômenos como a globalização, pressupõe uma conjugação da comunidade internacional aliada ao direito constitucional contemporâneo, proporcionando, como afirma Theófilo Antônio Miguel Filho em sua tese de doutorado, "a atuação de um Estado constitucional cooperativo, aberto, plenamente participativo e integrado à comunidade internacional, tendente a cooperar com o desenvolvimento mundial e promover a redução de barreiras e desigualdades".

Em FILHO, Theophilo Antônio Miguel; ARAUJO, Nádia de. Questões constitucionais e legais da Convenção da Haia sobre os aspectos civis do sequestro internacional de crianças. Rio de Janeiro, 2010. Tese de Doutorado - Departamento de Direito, Pontifícia Universidade Católica do Rio de Janeiro, p. 13.
} 
(nacional) que tradicionalmente determinavam as regras sobre as relações interpessoais dos cidadãos de cada país ${ }^{4}$.

Vale ressaltar que tal conjuntura evidentemente gera um refinamento das normas, na medida em que o sistema jurídico tradicional fechado não mais satisfaz a escala cada vez mais ampla do elo entre os entes de diferentes comunidades.

No âmbito do Direito Internacional Público, um exemplo dessa maior aproximação de entes Estatais está na participação dos mesmos, inclusive do Brasil, em Tratados e Convenções pois, diante de normas de caráter específico capazes de garantir a rapidez e eficácia no trânsito dos requerimentos internacionais de atos processuais e jurisdicionais, surge a possibilidade de criarem vínculo entre si, seja estipulando direitos e obrigações, seja na própria criação de normas unificadas.

Já as regras de Direito Internacional Privado ofereceram respostas às situações que possuem um elemento de estraneidade ${ }^{5}$, em função do advento dessa nova realidade que trouxe a exigência de maior diálogo para garantir a coexistência pacífica entre as pessoas.

Sabemos que as relações humanas são difíceis e, muitas vezes, problemáticas. Assim, quando a dinâmica destas relações sofre algum tipo de mutação, sendo, por fim, interrompida, é importante que tenhamos mecanismos a disposição para dirimir os conflitos resultantes destas situações a fim de que as partes possam seguir com suas vidas ajustando-se às suas novas realidades.

Não diferente deste cenário, verificamos uma mudança na estrutura familiar em geral, agora muitas vezes composta por uma relação entre

\footnotetext{
4 RAMOS, André de Carvalho. Op. Cit. apud DELMAS-MARTY, Mireille. Le pluralisme ordonné. Paris: Seuil, 2004.

5 "As fontes materiais do DIPr são consequências da "sociedade que se move "e não obedece às fronteiras políticas de um estado: os fatos transnacionais são aqueles eventos do mundo fenomênico com elemento (ou vínculo) de estraneidade" Ibid. p. 600.
} 
pessoas de origens e culturas diferentes. Muitas vezes isso significa a saída de uma das partes do seu país para o ambiente do outro, tendo que aprender e vivenciar a cultura alheia com o intuito de construir ali uma família.

Destarte, com as famílias sempre em movimento, inevitavelmente, surgem eventuais conflitos familiares, e tornou-se comum a prática do retorno ao país de origem, gerando polêmica quanto a questões sobre divórcio, partilha de bens e guarda dos filhos.

Este último, conforme à dificuldade dos pais em chegar a um acordo satisfatório que possibilite, acima de tudo, o bem-estar de seus filhos, garantindo mútua convivência ao longo de seu crescimento, levando em conta as circunstâncias peculiares de sua nova situação familiar, vem resultando em inúmeros $\operatorname{casos}^{6}$ de sequestro de menores por um destes genitores.

Mediante estudos precisos e análise de estatísticas de vários países, pôde-se chegar à conclusão que este fenômeno vem ocorrendo em função não só do aumento da migração internacional e do casamento multicultural, como também em função do maior índice de divórcios.

O Brasil já se posicionou internacionalmente sobre a problemática da subtração do menor do local onde reside, conjuntamente com mais de 60 Estados $^{7}$, sendo signatário, no âmbito da Conferência de Haia, de duas convenções que dizem respeito às crianças: a Convenção sobre Adoção Internacional (1993) e a Convenção de Haia de 1980 sobre Sequestro

\footnotetext{
${ }^{6}$ Segundo estatísticas, os EUA têm o maior número de incidentes reportados no mundo, com 169 pedidos depositados em 2003 - de acordo com as estatísticas mais recentes compiladas pelo rapto da Convenção de Haia. Em contrapartida, o Canadá recebeu 56 pedidos de pais em busca de ter um filho de volta e fez 43 pedidos para que um filho retornasse a partir de outro país. Segundo a Secretaria de Direitos Humanos, hoje, existem 171 casos de crianças que foram sequestradas e aguardam retorno à sua residência habitual"

Em MÉRIDA, Carolina Helena. Sequestro Interparental: Princípio da residência habitual. Revista de Direito Internacional, Brasília, v. 8, n. 2, p. 255-272, jul./dez. 2011. Disponível em: < http://www.publicacoesacademicas.uniceub.br/index.php/rdi/article/download/1544/1435>. Acesso em: 9 mai. 2015

${ }^{7}$ Disponível em: < http://www.hcch.net/index_en.php?act=conventions.status\&cid=24>. Acesso em: 10 mai. 2015
} 
Internacional de Menores ${ }^{8}$, como forma de aprimorar a cooperação jurídica e aproximar os países de soluções eficientes e uniformes.

Para os fins deste trabalho, nos concentraremos na segunda convenção, sob o foco da subtração ilícita do menor. Vale ressaltar que o tema vem gerando enorme repercussão pois, apesar da Convenção de Haia trazer regras que tratam da prevenção e repressão da prática, ainda existem questões concernentes que causam dúvidas e controvérsias argumentativas, fator que prejudica o momento de sua aplicação interna e seu cumprimento efetivo pelos sistemas dos países-membros.

Exporemos brevemente as exceções ao retorno do menor contidas na Convenção de Haia, focando e aprofundando apenas nas controvérsias existentes no Artigo 13, alínea b, quanto às indeterminações teóricas que geram dificuldades práticas na aplicação das situações expressas no artigo em casos concretos.

Ainda, nos confrontaremos com casos de violência doméstica, avaliando se seria possível os encaixar ou não nas hipóteses do Artigo 13, alínea $b$, em decorrência do vasto crescimento de alegações deste porte, demonstrando como os Estados-membros lidam com a dificuldade na falta de previsão expressa na respectiva Convenção.

Diante deste contexto partiremos, posteriormente, para a investigação de jurisprudência estrangeira e brasileira de forma conjunta, a fim de apresentar algumas soluções que possam melhorar a efetiva aplicação das regras estabelecidas no ordenamento brasileiro.

\footnotetext{
${ }^{8}$ Disponível em: <http://www.stf.jus.br/convencaohaia/cms/verTexto.asp?pagina=conferenciaInternacional > Acesso: 17 mai. 2015
} 


\section{CAPÍTULO 1 - A CONVENÇÃO DE HAIA DE 1980 SOBRE SEQUESTRO INTERNACIONAL DE MENORES}

\subsection{O contexto global da Convenção de Haia}

A Convenção de Haia sobre Sequestro Internacional de Menores de 1980 ("Convenção") busca combater o sequestro parental entre seus Estados-membros por meio da cooperação direta entre as autoridades centrais $^{9}$ e um procedimento célere no retorno da criança ao país de sua residência habitual, com fulcro no princípio do melhor interesse do menor.

Como exposto previamente, a Convenção possui objetivos claros, definidos em seu Artigo $1^{\circ}$, abaixo:

\footnotetext{
“A presente Convenção tem por objeto: a) Assegurar o regresso imediato das crianças ilicitamente transferidas para qualquer Estado Contratante ou nele retidas indevidamente; b) Fazer respeitar de maneira efetiva nos outros Estados Contratantes os direitos de custódia e de visita existentes num Estado Contratante".
}

Logo, o ideal almejado pela Convenção é restabelecer o status quo, o pronto retorno, com base na celeridade, que se mostrou imprescindível para o melhor interesse da criança, pois não é interessante que a mesma precise passar por um processo de adaptação.

Não obstante, para a decretação do retorno, foi estabelecido ser primordial a comprovação de que a transferência ou retenção do menor foi ilícita, havendo dependência da aplicação do direito estrangeiro, ou seja, é preciso analisar a lei material do país que reside a criança para que se possa definir se houve ou não caracterização de ilicitude ${ }^{10}$.

\footnotetext{
${ }^{9}$ Artigo $7^{\circ}$. As autoridades centrais devem cooperar entre si e promover a colaboração entre as autoridades competentes dos seus respectivos Estados, por forma a assegurar o regresso imediato das crianças e a realizar os outros objetivos da presente Convenção.

Disponível em: <http://www.planalto.gov.br/ccivil_03/decreto/D3413.htm〉. Acesso em: 20 abr. 15.

${ }^{10}$ A caracterização da ilicitude do ato de remoção ou retenção da criança é composto, segundo Eliza Pérez-Vera, pelo elemento fático (o efetivo exercício dos direitos referentes à guarda em
} 
Neste sentido, o Artigo $3^{\circ}$, definiu como ilícita a transferência quando a) tenha havido violação do direito de guarda de acordo com a lei do domicílio da criança e b) efetivo exercício deste direito no momento da transferência ${ }^{11}$.

Portanto, a transferência só pode ocorrer de um país para outro quando há entre os genitores um acordo, ou uma decisão judicial ou medida legal equivalente do local da residência habitual da criança. Neste intuito, fundamental que sejam respeitadas as normas "do outro", que haja a promoção do respeito às regras sobre direito estrangeiro de custódia e guarda de cada um dos Estados-membros, visando manter a pacificidade na relação entre os genitores, visto que o vínculo, em si, sempre existirá.

Como se vê, para que estes objetivos da Convenção sejam alcançados, é mister que haja uma comunicação - que abarque as três esferas de poder (administrativo, legislativo e judiciário) - entre o país de onde a criança foi sequestrada e o país para onde ela foi levada, que atuem em conjunto, com o mesmo propósito.

Este apoio mútuo se opera pelo mecanismo da cooperação jurídica internacional, caracterizada pelo intercâmbio amplo entre Estados soberanos de atos públicos com o objetivo de conferir segurança e estabilidade nas relações internacionais. Se os países soberanos não se organizarem na cooperação jurídica para estabelecer métodos convergentes

momento atual, qual seja anterior à transferência da criança) e pelo elemento jurídico (relação entre o direito de guarda do genitor atribuído pela Convenção conjuntamente com o direito que lhe atribui o Estado-membro sobre a residência habitual da criança).

Em TIBURCIO, Carmen; CALMON, Gulherme. Sequestro Internacional de Menores: comentários à Convenção de Haia de 1980, São Paulo: Atlas, 2014, p. 92.

${ }^{11}$ Artigo $3^{\circ}$. A transferência ou a retenção de uma criança é considerada ilícita quando: a) tenha havido violação a direito de guarda atribuído a pessoa ou a instituição ou a qualquer outro organismo, individual ou conjuntamente, pela lei do Estado onde a criança tivesse sua residência habitual imediatamente antes de sua transferência ou da sua retenção;

b) esse direito estivesse sendo exercido de maneira efetiva, individual ou em conjuntamente, no momento da transferência ou da retenção, ou devesse está-lo sendo se tais acontecimentos não tivessem ocorrido. O direito de guarda referido na alínea a) pode resultar de uma atribuição de pleno direito, de uma decisão judicial ou administrativa ou de um acordo vigente segundo o direito desse Estado.

Disponível em: 〈http://www.planalto.gov.br/ccivil_03/decreto/D3413.htm〉. Acesso em: 20 abr. 15. 
de atuação, ocorrerá, inevitavelmente, uma insegurança profunda nessas relações.

Este sistema de cooperação ${ }^{12}$, utilizado para atender as demandas cada vez mais recorrentes de casos de abdução destes menores, é o mecanismo mais direto e engenhoso entre autoridades administrativas, sendo estas responsáveis por concretizar em seu território as regras internacionais estabelecidas. É um princípio internacional decorrente do conceito da soberania de cada Estado em exercer sua própria jurisdição ${ }^{13}$.

Neste sentido, em seu Artigo $7^{\circ}$, estabelece que a autoridade central tem a obrigação de tomar todas as medidas que sejam adequadas para a devolução voluntária do menor, além de assistir a parte quanto ao procedimento quando em casos em que não há acordo pacífico e prevenir que futuros atos ilícitos sejam praticados ${ }^{14}$.

Tais medidas estatais devem atentar para questões temporais, visto que quando a criança atingir seus dezesseis $\operatorname{anos}^{15}$, não mais terá a proteção internacional deste instituto. Em conjunto a isso, muitas vezes, têm-se visto situações em que a criança é retirada do país enquanto legalmente

\footnotetext{
${ }^{12}$ A cooperação jurídica internacional pode se dar, em regra, pela via judicial (quando da expedição de cartas rogatórias e homologação de sentenças estrangeiras pelo STJ), ou perante a via extrajudicial (auxílio direto entre as autoridades administrativas).

${ }^{13}$ Isso significa que no curso de um processo os juízos precisam cooperar, visto que não há nenhum poder judiciário que tenha poderes extraterritoriais, não sendo possível juiz algum unilateralmente dar uma ordem a outro Estado para que este cumpra uma determinada obrigação.

${ }^{14}$ Artigo $7^{\circ}$. Em particular, deverão tomar, quer diretamente, quer através de um intermediário, todas as medidas apropriadas para: a) Localizar uma criança deslocada ou retida ilicitamente; b) Evitar novos danos à criança, ou prejuízos às partes interessadas, tomando ou fazendo tomar medidas provisórias; c) Assegurar a reposição voluntária da criança ou facilitar uma solução amigável; d) Proceder à troca de informações relativas à situação social da criança, se isso se considerar de utilidade; e) Fornecer informações de carácter geral respeitantes ao direito do seu Estado, relativas à aplicação da Convenção; f) Introduzir ou favorecer a abertura de um procedimento judicial ou administrativo que vise o regresso da criança ou, concretamente, que permita a organização ou o exercício efetivo do direito de visita; g) Acordar ou facilitar, conforme as circunstâncias, a obtenção de assistência judiciária e jurídica, incluindo a participação de um advogado; h) Assegurar no plano administrativo, se necessário e oportuno, o regresso sem perigo da criança; i) Manterem-se mutuamente informados sobre o funcionamento da Convenção e, tanto quanto possível, eliminarem os obstáculos que eventualmente se oponham à aplicação desta.

Disponível em: <http://www.planalto.gov.br/ccivil_03/decreto/D3413.htm>. Acesso em: 25 abr. 15.

${ }^{15}$ Artigo $4^{\circ}$. A Convenção aplica-se a qualquer criança que tenha residência habitual num Estado Contratante, imediatamente antes da violação do direito de guarda ou de visita. A aplicação da Convenção cessa quando a criança atingir a idade de dezesseis anos.
} 
amparada, mas devido à demora do procedimento cabível passa a não ser mais salvaguardada pela Convenção.

Quer dizer, há casos em que, no aguardo da tomada de uma decisão, a criança é desprovida de qualquer contato com um ente familiar, além de ser forçada a se adaptar em um outro país cuja cultura, língua e estrutura social se divergem da sua.

A adaptação a um novo ambiente é a exceção, e não a regra. Não deve ocorrer pela existência de um sistema arrastado, cujos anos até uma conclusão impõem ao menor abraçar uma nova vida.

Daí a importância de uma atuação rápida e assertiva por parte do Estado para o qual a mesma foi levada, de modo a evitar que seu retorno seja o menos traumático possível ${ }^{16}$. O procedimento interno precisa ser célere e efetivo. Sem um aparelho jurisdicional adequado e suficiente, seus objetivos dificilmente serão alcançados.

Outro ponto de igual relevância refere-se ao tema da residência habitual.

A Convenção é válida para qualquer criança que tenha residência habitual em um Estado-parte se antes do sequestro, não podendo ser aplicada no caso de um dos países não serem signatários. No entanto, é sabido que não há definição incontroversa sobre este conceito. Por efeito da ausência de critérios que o determinem, remanescem discussões sobre a matéria.

Elisa Pérez-Vera, relatora da Convenção e autora do Explanatory Report sobre a Convenção, publicado pela Conferência de Haia de Direito Internacional Privado em 1981, compreende ser este um conceito

\footnotetext{
${ }^{16}$ Cartilha Outline Hague Child Abduction Convention. The Convention of 25 October 1980 on the Civil Aspects of International Child Abduction. Disponível em: <http://www.hcch.net/upload/outline28e.pdf>. Acesso em: 20 abr. 2015.
} 
meramente fático, ou seja, o olhar da questão deve ser apenas objetivo ${ }^{17}$. Portanto, a residência seria simplesmente o local onde a criança está ${ }^{18}$.

Já outras visões envolvem a consideração de aspectos que vão além da constatação fática, podendo ser a da perspectiva do menor, do acordo entre os genitores, englobando questões jurídicas, todas em conjunto ou separadamente.

Uma definição bastante regular entre os países, como bem retrata Renata Gaspar e Guilherme Amaral em sua pesquisa sobre a aplicação da Convenção nos Tribunais brasileiros, envolve uma mistura de habitualidade e intencionalidade, sobre a qual "a residência habitual para o Direito Internacional privado é o lugar onde uma pessoa reside por um período considerável e regular, e ali constitui seu centro da vida, desenvolvendo relações, intimidade, etc ${ }^{19}$ ".

Até este ponto da discussão é possível chegar à seguinte lógica:

A identificação da residência habitual é importante para 1) determinar a lei aplicável sobre a guarda e, consequentemente, concluir se houve ou não a retenção ilícita e 2) definir a regra de competência.

Sobre a competência, é comum que seja definida a da justiça local de onde mora a criança, sendo o juiz do país de residência habitual o mais adequado para decidir a causa. Isto porque acautela-se no princípio do juiz

\footnotetext{
17 PÉREZ-VERA, Elisa. Explanatory Report, 1981. Disponível em: <http://www.hcch.net/index_en.php?act=publications.details\&pid=2779>.

18 TIBURCIO, Carmen. Curso sobre Sequestro Internacional de Crianças. Convenção da haia sobre sequestro de menores: residência habitual, em palestra no TRF da $4^{\mathrm{a}}$ região sobre Sequestro Internacional de Menores. Disponível em: <http://www2.trf4.jus.br/trf4/controlador.php?acao=pagina_visualizar\&id_pagina=1220\#MATERI AIS >. Acesso em: 2 mai. 15.

19 BRANT, Leonardo Nemer Caldeira; LAGE, Délber Andrade; CREMASCO, Suzana Santi (Coord.). Direito internacional contemporâneo. Curitiba: Juruá, 2011, p. 54-55, apud GASPAR, Renata; AMARAL, Guilherme. Sequestro internacional de menores: os tribunais brasileiros têm oferecido proteção suficiente ao interesse superior do menor? Meritum, Belo Horizonte, v. 8 - n. 1, 2013, p. 351-387. Disponível em: <http://www.sdh.gov.br/assuntos/adocao-e-sequestrointernacional/legislacao-e-publicacoes/sequestro-internacional-de-menores-os-tribunaisbrasileiros-tem-oferecido-protecao-suficiente-ao-interesse-superior-do-menor>. Acesso em: 2 mai. 15 .
} 
natural, entendendo ser a pessoa que contém condições para verificar o melhor interesse da criança ${ }^{20}$.

O juiz do local onde a criança possui sua residência habitual é considerado ser mais capaz de trazer ao processo informações mais precisas quanto ao prisma social do local, contextualizar de fato o ambiente em que o menor se encontra e conseguir, enfim, discutir de modo mais profundo os aspectos da guarda.

O fato é que a Convenção não regra a discussão sobre a guarda ${ }^{21}$, sendo o pedido limitado à problemática do retorno ou não da criança ao país do qual foi retirada ilicitamente, devendo a questão envolvendo a guarda do menor ser resolvida internamente pela justiça competente do país, após o retorno da criança a sua residência habitual ${ }^{22}$.

Nestes termos, em seu artigo, Mérida esclarece:

"Por isso não comportam nos processos de sequestro internacional a discussão acerca de eventuais direitos decorrentes da guarda, devendo isso ser resolvido pelo juízo de competência natural, o qual é o Estado de residência habitual da criança, antes da ocorrência de sua transferência ou retenção. Logo, a contenda nos casos de Sequestro Interparental sobre direito de guarda da criança se revela igualmente imprópria, via de consequência, a discussão acerca de quem possuiria condições de oferecer melhor qualidade de vida ao menor também é de todo infrutífera"23.

O conceito de direito de guarda da Convenção compreende o cuidado, ainda que o genitor tenha apenas direito de visitação - agregado (ou não) ao direito de decidir o local de residência habitual, o que lhe dá legitimidade para pedir a restituição de uma criança. Diante disso, a

\footnotetext{
${ }^{20}$ TIBURCIO, Carmen. Op. Cit.

${ }^{21}$ TIBURCIO, Carmen; CALMON, Guilherme. Op. Cit., p. 110.

${ }^{22}$ Artigo 16. Depois de terem sido informadas da transferência ou retenção ilícitas de uma criança, nos termos do Artigo 3, as autoridades judiciais ou administrativas do Estado Contratante para onde a criança tenha sido levada ou onde esteja retida não poderão tomar decisões sobre o fundo do direito de guarda sem que fique determinado não estarem reunidas as condições previstas na presente Convenção para o retorno da criança ou sem que haja transcorrido um período razoável de tempo sem que seja apresentado pedido de aplicação da presente Convenção.

${ }^{23}$ MÉRIDA, 2010, p. 268.
} 
titularidade deste direito convencional de guarda será determinada segundo o regulamento pátrio do país que seja a residência habitual da criança ${ }^{24}$.

Ou seja, se o genitor não foi destituído do poder familiar, ele possui o direito de decisão da residência habitual da criança ${ }^{25}$.

Para promover o retorno da criança à situação anterior a sua retirada, a Convenção instituiu a possibilidade de proposição de ação de restituição ${ }^{26}$, instrumento útil no período de até um ano do sequestro, salvo

${ }^{24}$ CONVENÇÃO DE HAIA SOBRE ASPECTOS CIVIS DO SEQUESTRO INTERNACIONAL DE CRIANÇAS, DE 25/10/80 - DECRETO N. ${ }^{\circ}$ 3.413/2000 - COOPERAÇÃO JUDICIÁRIA INTERNACIONAL - RESTITUIÇÃO DE MENORES À NORUEGA - A UNIÃO FEDERAL É PARTE LEGÍTIMA PARA FIGURAR NO PÓLO ATIVO DA DEMANDA - PRECEDENTES DO STJ E DO TRF-2 ${ }^{a}$ REGIÃO - GUARDA E JURISDIÇÃO (ARTS. 16, 17 E 19 DO DECRETO N. ${ }^{\circ}$ 3.413/2000) - SEGURANÇA DENEGADA. I-A cooperação judiciária internacional pode se dar pela via da carta rogatória, através da homologação de sentença estrangeira ou diretamente, como é o caso dos autos, hipótese em que a União Federal não pretende executar em solo nacional a sentença estrangeira, mas tão-somente obter uma "decisão brasileira de restituição dos menores à Noruega", com base na Convenção de Haia sobre os Aspectos Civis do Seqüestro Internacional de Crianças, à qual o Brasil aderiu, tendo-a incorporado ao ordenamento jurídico pátrio. II-A Convenção da Haia sobre os Aspectos Civis do Sequestro Internacional de Crianças - internalizada pelo ordenamento jurídico pátrio por meio do Decreto 3.413, de 14 de abril de 2000 - prevê explicitamente a promoção de medidas judiciais tendentes à restituição ao país de residência habitual de menores ilicitamente transferidos para o território nacional. III- A União postula, pela via oblíqua, os interesses da Noruega - Estado requerente da cooperação judiciária internacional - de ver restituídos para o seu território os menores que ali residiam até o momento da ilícita transferência para o Brasil. IV- Em sede de cooperação judiciária direta, não se busca o cumprimento de ordem judicial estrangeira, pretendendo-se, no caso vertente, a obtenção de decisão brasileira de restituição dos menores à Noruega. VPrecedentes: STJResp 954.877; TRF-2 ${ }^{\mathrm{a}}$ REGIÃO AC 200551010097929). VI- A questão da guarda e a jurisdição apropriada para apreciá-la são matérias disciplinadas pela Convenção da Haia nos dispositivos dos arts. 16, 17 e 19, não cabendo à Justiça brasileira tomar para si o conhecimento de questão que compete à jurisdição de outro Estado. VII- Ainda que exista decisum do Judiciário Brasileiro definindo questões de guarda e visitas, o Estado Brasileiro, por meio do Poder Judiciário, não pode negar pedido de restituição de menores se os requisitos do Tratado estiverem presentes. VIII- A decisão tomada nos autos de ação de guarda não pode impedir o cumprimento de decisão que deferiu a restituição dos menores, ou mesmo prejudicar o prosseguimento da ação por meio da qual se busca tal devolução, sob pena de afronta aos compromissos internacionais da República Federativa do Brasil assumidos quando da ratificação e internalização da Convenção de Haia sobre os Aspectos Civis do Sequestro Internacional de Crianças. IX- Segurança denegada, cassando-se liminar ab initio concedida no presente mandamos. (MS 2009.02.01.004118-6 TRF $2^{\mathrm{a}}$ Região, $8^{\mathrm{a}}$ Turma Especializada, Data do Julgamento: 28/07/2009, Relator (a) DESEMBARGADOR FEDERAL Raldenio Bonifacio)

${ }^{25}$ MARTINS, Nathalia Camba. Curso sobre Sequestro Internacional de Crianças. Conferência 6: "Exceções à Obrigação de Retorno Imediato de Crianças Vítimas de Subtração Internacional (artigos 12, 13 e 20 da Convenção de Haia de 1980), em palestra no TRF da $4^{a}$ região sobre Sequestro Internacional de Menores. Disponível em: <http://www2.trf4.jus.br/trf4/controlador.php?acao=pagina_visualizar\&id_pagina=1220\#MATERI AIS>. Acesso em: 5 mai. 15

${ }^{26}$ Artigo 12. Quando uma criança tiver sido ilicitamente transferida ou retida nos termos do Artigo 3 e tenha decorrido um período de menos de 1 ano entre a data da transferência ou da retenção indevidas e a data do início do processo perante a autoridade judicial ou administrativa do Estado Contratante onde a criança se encontrar, a autoridade respectiva deverá ordenar o retomo imediato 
exceções (dispostas em seus Artigos 12, 13 e 20) ${ }^{27}$. Após este período, se o pedido for validado, deve-se adicionar à investigação, sob o aspecto subjetivo, a probabilidade de o retorno ser ainda mais prejudicial.

Entende-se que não é obrigatório o retorno do menor, por exemplo, nas situações em que as autoridades centrais atuem em um período inferior a um ano ou após este.

O que se extrai do texto quanto ao prazo de um ano é o seguinte: 1) com menos de um ano a criança deverá retornar, sem abordar o ponto subjetivo da adaptação, por se entender não ser cabível produzir prova de qualquer adaptação ao novo ambiente em um tempo tão remoto; 2) passado o período de um ano, deverá retornar, salvo a criança já estiver adaptada.

O termo inicial da contagem do prazo possui ainda muita discussão. Um entendimento é que este se dá do início do procedimento administrativo de restituição pelo genitor abandonado.

Outras conjunturas que igualmente ensejam exceções são aquelas em:

\footnotetext{
da criança. A autoridade judicial ou administrativa respectiva, mesmo após expirado o período de um ano referido no parágrafo anterior, deverá ordenar o retorno da criança, salvo quando for provado que a criança já se encontra integrada no seu novo meio. Quando a autoridade judicial ou administrativa do Estado requerido tiver razões para crer que a criança tenha sido levada para outro Estado, poderá suspender o processo ou rejeitar o pedido para o retomo da criança.

${ }^{27}$ Artigo 13. Sem prejuízo das disposições contidas no Artigo anterior, a autoridade judicial ou administrativa do Estado requerido não é obrigada a ordenar o retomo da criança se a pessoa, instituição ou organismo que se oponha a seu retomo provar: a) que a pessoa, instituição ou organismo que tinha a seu cuidado a pessoa da criança não exercia efetivamente o direito de guarda na época da transferência ou da retenção, ou que havia consentido ou concordado posteriormente com esta transferência ou retenção; ou b) que existe um risco grave de a criança, no seu retorno, ficar sujeita a perigos de ordem física ou psíquica, ou, de qualquer outro modo, ficar numa situação intolerável. A autoridade judicial ou administrativa pode também recusar-se a ordenar o e retorno da criança se verificar que esta se opõe a ele e que a criança atingiu já idade e grau de maturidade tais que seja apropriado levar em consideração as suas opiniões sobre o assunto. Ao apreciar as circunstâncias referidas neste Artigo, as autoridades judiciais ou administrativas deverão tomar em consideração as informações relativas à situação social da criança fornecidas pela Autoridade Central ou por qualquer outra autoridade competente do Estado de residência habitual da criança.

Artigo 20. O retomo da criança de acordo com as disposições contidas no Artigo $12^{\circ}$ poderá ser recusado quando não for compatível com os princípios fundamentais do Estado requerido com relação à proteção dos direitos humanos e das liberdades fundamentais.
} 
a) que a pessoa, instituição ou organismo que tinha a seu cuidado a pessoa da criança não exercia efetivamente o direito de guarda na época da transferência ou da retenção, ou que havia consentido ou concordado posteriormente com esta transferência ou retenção; ou

b) que existe um risco grave de a criança, no seu retorno, ficar sujeita a perigos de ordem física ou psíquica, ou, de qualquer outro modo, ficar numa situação intolerável $^{28}$.

Primeiramente, vale saber que deve se analisar, antes de tudo, a situação da criança antes da remoção para saber se houve ou não violação da guarda. Deste modo, o dispositivo estabelece que havendo a existência de grave risco (físico ou psicológico), situação intolerável, a recusa da criança, bem como o consentimento do genitor abandonado quanto a permanência no outro país, o retorno não deve ocorrer.

Acontece que a aplicação destas exceções é circunstanciada à análise do caso em concreto, atendendo às suas especificidades. Apesar disso, tais situações trazem inúmeras discussões a serem examinadas e destrinchadas com calma mais à frente.

Inicialmente, é mister verificar como alguns aspectos específicos da Convenção de Haia de 1980 se reflete sob o ordenamento jurídico brasileiro.

\subsection{A Convenção no Brasil}

Apesar de ter sido elaborada em 1980, a Convenção foi promulgada pelo Brasil apenas em 14 de abril de 2000, através do Decreto Presidencial $n^{0} 3.413$, sendo o primeiro instrumento de nossa legislação a dar proteção ao menor que era retirado ilicitamente de seu país de domicílio ${ }^{29}$.

Por meio da integração entre o direito público e o direito privado, sob a égide dos direitos humanos protegidos pela nossa Constituição, este

\footnotetext{
${ }^{28}$ Artigo 13 da Convenção de Haia de 1980 sobre Sequestro Internacional de Menores. Disponível em: <http://www.planalto.gov.br/ccivil_03/decreto/D3413.htm>. Acesso em: 29 abr. 15

${ }^{29}$ ARAUJO, Nádia de. Direito internacional privado: teoria e prática brasileira. Rio de Janeiro: Renovar, 2006, p. 554-555.
} 
conjunto de normas vem suprir, a priori, a necessidade de regulamentação e harmonização nos foros internacionais.

Antes de a Convenção vigorar no Brasil, sob o aspecto específico do sequestro, não havia uma comunicação direta entre as autoridades centrais dos países (auxílio direto). Isto dificultava a atuação dos genitores que, por conta própria, ingressavam com uma ação no estrangeiro. E, quando proferida sentença determinando o retorno da criança, era necessária a homologação pelo Supremo Tribunal Federal ${ }^{30}$.

Antes, o recurso que obtinha um dos pais que se mudou com a criança à revelia do outro era um pedido de retorno requerido ao juiz local, que dependia que a decisão fosse enviada para o juiz estrangeiro.

Deste modo, o pedido de restituição era formalizado através das cartas rogatórias. No entanto, por acreditar à época se tratar de violação a ordem pública, o Brasil não concedia exequatur ("cumpra-se") às medidas de caráter executório ${ }^{31}$, ou seja, negava-se o pedido de retorno da criança sempre que da ausência de sentença proferida sobre a questão, e de sua homologação. Em vista disso, na realidade, a criança acabava não retornando ao país do qual foi sequestrada.

\footnotetext{
30 A partir de 2005, o responsável pela homologação de sentenças estrangeiras passou a ser o Superior Tribunal de Justiça, conforme estabelecido pela Resolução n ${ }^{\circ} 9$ do STJ, em seu Artigo $4^{\circ}$. Por via deste determinou-se o procedimento quanto à concessão de cartas rogatórias e à homologação de sentença estrangeira, sendo apenas com esta última ser possível dar eficácia a um ato judicial estrangeiro.

31 A carta rogatória executória é aquela que contém uma ordem que vai exigir um ato de constrição. Antigamente, o STJ recusava de plano qualquer pedido do exterior que tivesse caráter executório, por entender que esse tipo de pedido não cabia em carta rogatória. Essa resolução permitiu expressamente que essas cartas tivessem caráter executório. Na verdade, isso não significa que elas serão deferidas de plano, mas sim que agora elas serão analisadas, o que não se fazia no passado, quando a recusa era automática. A título exemplificativo, algumas medidas executórias realizadas se referiam a pedidos de busca e apreensão de menores, questões sobre alimentos provisórios e quebra de sigilo telefônico.
} 
A referida problemática foi resolvida através da Resolução $n^{\circ} 9$ do Superior Tribunal de Justiça, permitindo que as cartas rogatórias tivessem como objeto atos executórios ${ }^{32}$.

Ademais, com a vinda da Convenção, instaurou-se o sistema da cooperação entre as entidades administrativas, determinando que as informações e comunicações entre os países passariam a ser feitas por meio das autoridades centrais. Além disso, criou uma ação própria para o retorno do menor.

O Decreto designou como autoridade central a Secretaria de Direitos Humanos da Presidência da República $(\mathrm{SDH} / \mathrm{PR})^{33}$, órgão estruturado dentro do Ministério da Justiça, tendo como função primordial estabelecer a comunicação com outras autoridades centrais, bem como buscar meios mais eficientes para o retorno imediato das crianças e solucionar o problema amigavelmente.

Recentemente, em janeiro de 2014, foi instituída a Comissão Permanente sobre Subtração internacional de Crianças ${ }^{34}$ pela própria

\footnotetext{
${ }^{32}$ Art. $7^{\circ}$ da Resolução $\mathrm{n}^{\circ}$ 9: "As cartas rogatórias podem ter por objeto atos decisórios ou não decisórios. Parágrafo único. Os pedidos de cooperação jurídica internacional que tiverem por objeto atos que não ensejem juízo de delibação pelo Superior Tribunal de Justiça, ainda que denominados como carta rogatória, serão encaminhados ou devolvidos ao Ministério da Justiça para as providências necessárias ao cumprimento por auxílio direto".

${ }^{33}$ BRASIL. Decreto n. 3.951, de 4 de outubro de 2001. Designa a Autoridade Central para dar cumprimento às obrigações impostas pela Convenção sobre os Aspectos Civis do Seqüestro Internacional de Crianças, cria o Conselho da Autoridade Central Administrativa Federal contra o Seqüestro Internacional de Crianças e institui o Programa Nacional para Cooperação no Regresso de Crianças e Adolescentes Brasileiros Seqüestrados Internacionalmente. Diário Oficial da União, 5 out. 2001. Art. $1^{\circ}$ Fica designada como Autoridade Central, a que se refere o art. $6^{\circ}$ da Convenção sobre os Aspectos Civis do Seqüestro Internacional de Crianças e Adolescentes, concluída em Haia, em 25 de outubro de 1980, aprovada pelo Decreto Legislativo $\mathrm{n}^{\circ} 79$, de 12 de junho de 1999, e promulgada pelo Decreto ${ }^{\circ}$ 3.413, de 14 de abril de 2000, a Secretaria de Estado dos Direitos Humanos do Ministério da Justiça. Disponível em: $<$ http://www2.camara.leg.br/legin/fed/decret/2001/decreto-3951-4-outubro-2001-404127publicacaooriginal-1-pe.html> Acesso em: 10 mai. 15.

${ }^{34}$ A competência da Comissão é de: I - estudar e propor iniciativas de prevenção à subtração e retenção internacional de crianças e adolescentes; II - propor medidas de divulgação da Convenção sobre Subtração e Retenção Ilícita de Crianças e Adolescentes e da Convenção de Haia sobre Aspectos Civis do Sequestro Internacional de Crianças, bem como de capacitação de agentes públicos e operadores do direito envolvidos em sua aplicação; III - propor procedimentos administrativos conjuntos a serem adotados em casos em que houver alegação de ocorrência de violência doméstica contra a mulher, bem como contra criança e adolescente; IV - elaborar propostas de atos normativos com vistas ao aprimoramento da implementação da Convenção
} 
SDH/PR, através da Portaria $n^{\circ} 34$, cuja finalidade é criar métodos que promovam o implemento efetivo das convenções sobre sequestro pelo Brasil.

O Brasil recebe o pedido de cooperação jurídica internacional para restituir a criança ou dar cumprimento ao pedido de visitação internacional. Este pedido é feito pelo estado estrangeiro ao brasileiro (cooperação passiva $)^{35}$ no intuito de buscar um acordo entre os genitores, seja sobre o retorno voluntário, seja quanto a definição do direito de visita ${ }^{36}$.

Tem-se verificado, como um dos métodos de aprimoramento da aplicação da Convenção, o uso do instrumento da mediação. O ideal seria incentivar cada vez mais uma maior cooperação entre os atores, que as partes busquem um acordo fora do âmbito tradicional da jurisdição, com uma única finalidade: o bem-estar da criança, que precisa voltar para o local de onde saiu ilicitamente.

A solução amigável apresenta inúmeras vantagens, desde garantir a celeridade e eficiência que o poder judiciário vem encontrando dificuldades em proporcionar, até mesmo por se tratar de um procedimento cuja finalidade é preservar o relacionamento entre as partes posteriormente ao

Interamericana sobre Restituição Internacional de Menores e da Convenção de Haia sobre Aspectos Civis do Sequestro Internacional de Crianças; V - fomentar estudos e pesquisas sobre a implementação da Convenção Interamericana sobre Restituição Internacional de Menores e da Convenção de Haia sobre Aspectos Civis do Sequestro Internacional de Crianças; e VI - elaborar seu regimento interno. Informações divulgadas pela Secretaria de Direitos Humanos. Disponível em: <http://www.sdh.gov.br/assuntos/adocao-esequestro-internacional/sequestro-internacional/comissao-permanente>. Acesso em: 19/10/2015.

${ }^{35}$ Há ainda a modalidade da cooperação ativa, situação em que a criança é retirada ilicitamente do Brasil e este precisa se comunicar com o país para onde a criança foi levada. Nesta situação, o genitor entra em contato com a ACAF que recebe o pedido e encaminha para a Autoridade Central do país em que a criança se encontra. Havendo necessidade, a Autoridade Central requerida aciona a INTERPOL, podendo, ainda, acionar os Consulados brasileiros para prestarem apoio para o retorno da criança ao Brasil.

Em cartilha da Autoridade Central Administrativa do Brasil disponibilizada pela Secretaria de Direitos Humanos da Presidência da República. Disponível em: <http://www.sdh.gov.br/assuntos/adocao-e-sequestro-internacional/sequestrointernacional/arquivos-subtracao/convencao-de-haia-de-1980>. Acesso em: 11 mai. 15.

${ }^{36}$ BASTOS LOPES, Rosanne Christine Da Silva. Seqüestro Internacional De Crianças: Análise e estudo do caso do menino Sean. Brasília: Repositório UNICEUB, 2010, p. 17. 
acordo, fato que dificilmente ocorre no judiciário por este ser comumente conduzido como um processo adversarial.

À vista disso, estatísticas comprovam que, no período de 2002 a 2012, cerca de 109 casos foram encerrados por meio de acordo, o que demonstra uma porcentagem de $34 \%$ de soluções que almejam acima de tudo a convivência pacífica da criança com ambos os pais, provendo uma relação muito mais saudável entre as partes $^{37}$.

Apesar de em sua grande maioria (69 de um total de 109 casos) ter se estabelecido o retorno, cada caso decidido em prol do restabelecimento do status quo evita novos casos. Uma situação de sequestro de menores mina a confiança das crianças em seus pais e a família precisa encontrar suas próprias soluções, levando em conta suas particularidades.

Portanto, acordos devem ser incentivados e, uma vez obtidos, respeitados pelas partes e pelo judiciário.

Quando na ocorrência de impasse, não prevalecendo resolução pela mediação entre as partes, o caso é enviado ao órgão responsável pelo pedido de retorno do menor na esfera judicial para a promoção da ação cabível.

Quem tem atribuição para representar o Estado Brasileiro é a Advocacia Geral da União (AGU), seja internamente ou internacionalmente, visto que a secretaria responsável não possui personalidade jurídica própria ${ }^{38}$. Neste momento, as duas autoridades (AGU e SDH/PR) atuam em conjunto, somando esforços para garantir o cumprimento da Convenção.

\footnotetext{
${ }^{37}$ Estatísticas disponíveis em TIBURCIO, Carmen; CALMON, Gulherme. Op. Cit, p. 194-195.

${ }^{38}$ Id., Curso sobre Sequestro Internacional de Crianças. Conferência 6: "Exceções à Obrigação de Retorno Imediato de Crianças Vítimas de Subtração Internacional (artigos 12, 13 e 20 da Convenção de Haia de 1980). Disponível em: $<$ http://www2.trf4.jus.br/trf4/controlador.php?acao=pagina_visualizar\&id_pagina=1220\#MATERI AIS $>$. Acesso em: 5 mai. 15.
} 
A participação da União não é obrigatória. Se torna obrigatória somente quando por via de cooperação jurídica internacional. Na verdade, nada impede que a parte (genitor) se dirija diretamente às autoridades que põem determinar o retorno.

Já é pacífico na jurisprudência seu papel de representante do Estado Brasileiro, "assegurando-lhe tanto a condição de legitimada ativa ordinária, quanto de assistente litisconsorcial em hipóteses onde o cumprimento da Convenção Internacional é requerido diretamente por um dos genitores do menor" 39 .

Por isso, é importante ressaltar que a União defende interesse próprio, ou seja, na verdade, defende a cooperação internacional, voltada ao melhor interesse da criança, e não diretamente o genitor teve o filho sequestrado. Não se pode comparar a atuação da AGU com a atuação de um advogado privado ${ }^{40}$.

39 APELAÇÃO CÍVEL $\quad \mathrm{N}^{\mathrm{o}}$ 0001923-25.2008.4.03.6123/SP, Processo Originário 2008.61.23.001923 7/SP TRF $3^{\mathrm{a}}$ Região, $2^{\mathrm{a}}$ Turma, Data do Julgamento: 29/06/2010, Relatora Desembargadora Federal Cecília Mello. Ementa: DIREITO INTERNACIONAL E PROCESSUAL CIVIL. AÇÃO CAUTELAR DE BUSCA E APREENSÃO DE MENOR. CONVENÇÃO SOBRE OS ASPECTOS CIVIS DO SEQUESTRO INTERNACIONAL DE CRIANÇAS - CONVENÇÃO DE HAIA. UNIÃO. INTERESSE DE NATUREZA PÚBLICA. ASSISTÊNCIA LITISCONSORCIAL. RESIDÊNCIA HABITUAL. DEFINIÇÃO. INTERESSE DO MENOR. DIREITO INDISPONÍVEL. BUSCA DA VERDADE REAL. PODER INSTRUTÓRIO DO JUIZ. ARTIGO 130 DO CPC. NECESSIDADE DE DILAÇÃO PROBATÓRIA. DESCONSTITUIÇÃO DA SENTENÇA MONOCRÁTICA. AGRÁVO REGIMENTAL, APELAÇÃO E AÇÃO CAUTELAR INCIDENTAL PREJUDICADOS. 1. Trata-se de ação cautelar de busca e apreensão de menor supostamente removido do país de sua residência habitual, promovido pelo pai em face da mãe, com fulcro na Convenção sobre os Aspectos Civis do Sequestro Internacional de Crianças - Convenção de Haia -, promulgada pelo Decreto $\mathrm{n}^{\mathrm{o}} 3.413 / 2000$. 2. A intervenção da União no feito, na qualidade de assistente litisconsorcial, é de rigor, eis que o seu próprio interesse, de natureza pública, consiste no dever de cumprimento das obrigações assumidas em sede de Convenção Internacional, pode ser afetado (artigo 54, CPC). 3. Do teor do artigo $7^{\circ}$, letra f, da Convenção sobre os Aspectos Civis do Sequestro Internacional de Crianças, Convenção de Haia de 25.10.1980, promulgada pelo Decreto $\mathrm{n}^{\circ} 3.413 \mathrm{~m}$ de 14.04 .2000 , depreende-se não apenas a legitimidade ativa ad causam da União, mas especialmente o seu interesse, eis que designada, no Brasil, como autoridade central a Secretaria de Estado dos Direitos Humanos do Ministério da Justiça. 4. A jurisprudência não diverge acerca do interesse da União em casos análogos, assegurando-lhe tanto a condição de legitimada ativa ordinária, quanto de assistente em hipóteses onde o cumprimento da Convenção Internacional é requerido diretamente por um dos genitores do menor. Precedente: STJ, $2^{\mathrm{a}}$ Seção, CC 100.345, Rel. Min. LUIS FELIPE SALOMÃO, j. 11.02.2009, DJe 18.03.2009. 40 
A função da AGU é analisar se haveria a residência habitual e se a pessoa que está pedindo o retorno possui o direito convencional de guarda, podendo adotar medidas de urgência para a volta ao estado anterior ao sequestro.

O critério temporal para o estabelecimento destas medidas, conforme o Artigo 11 da Convenção ${ }^{41}$, é de seis meses para que a autoridade central requerida tome uma decisão sobre a questão. Caso contrário, deverá justificar a demora para o Estado requerente.

Preenchidos os requisitos da Convenção para a interposição, a ação é iniciada perante a Justiça Federal.

Nas palavras da Juíza Federal Monica Sifuentes (2009, p. 138):

"O Brasil é uma república federativa na qual coexistem duas ordens jurisdicionais: a federal, que julga os processos em que geralmente a União, suas autarquias e empresas públicas assumem a posição de parte; e a estadual, que julga os demais casos (exceto trabalhistas) como as causas relativas ao Direito de Família. À Justiça Federal tem sido reconhecida a competência para julgar os pedidos de restituição de menores, com base na Convenção da Haia de 1980. No entanto, não tem sido incomum serem as duas jurisdições acionadas para resolver a mesma situação do conflito decorrente de subtração ou retenção da criança no Brasil. Isso ocorre porque, em geral, os genitores ou os responsáveis pela subtração do menor, ao chegarem ao país, imediatamente se dirigem ao juiz de família nos estados para solicitar a sua guarda provisória, que geralmente não é negada pelos juízes. A Autoridade Central brasileira, por sua vez, ao receber o pedido de cooperação jurídica e ao não conseguir a restituição espontânea do menor, encaminha o caso para a AGU, que dá entrada no processo de restituição do menor no âmbito da Justiça Federal. Surge, desse modo, um elemento complicador, que é a existência de duas ações paralelas, uma na Justiça Federal, para decidir sobre a restituição do menor ao seu país de origem, com base na Convenção da Haia de 1980, e outra na Justiça Comum, com o objetivo de decidir com quem ficará a guarda. O impasse atrasa ainda mais o procedimento". 42

\footnotetext{
${ }^{41}$ Artigo 11. As autoridades judiciais ou administrativas dos Estados Contratantes deverão adotar medidas de urgência com vistas ao retomo da criança. Se a respectiva autoridade judicial ou administrativa não tiver tomado uma decisão no prazo de 6 semanas a contar da data em que o pedido lhe foi apresentado, o requerente ou a Autoridade Central do Estado requerido, por sua própria iniciativa ou a pedido da Autoridade Central do Estado requerente, poderá solicitar uma declaração sobre as razões da demora. Se for a Autoridade Central do Estado requerido a receber a resposta, esta autoridade deverá transmiti-la à Autoridade Central do Estado requerente ou, se for o caso, ao próprio requerente.

${ }^{42}$ SIFUENTES, Monica. Sequestro Interparental: a experiência brasileira na aplicação da Convenção de Haia de 1980. Revista da Seção Judiciária do Rio de Janeiro (SJRJ), Rio de Janeiro, n. 25, p. 135-144, 2009. Disponível em: < http://www.sdh.gov.br/assuntos/adocao-e-sequestrointernacional/legislacao-e-publicacoes/sequestro-interparental-a-experiencia-brasileira-naaplicacao-da-convencao-de-haia-de-1980 >. Acesso em: 15 mai. 2015.
} 
É sabido que no passado havia uma discussão sobre qual seria a justiça competente no Brasil para decidir sobre estes casos, se a Estadual ou a Federal.

No entanto, este conflito já está superado pela jurisprudência ${ }^{43}$, tendo sido estabelecido que é da competência da Justiça Federal a decisão sobre o retorno ou não da criança, por se encaixar nas situações dos incisos I, III e V do artigo 109 da Constituição de 1988, via decisão definitiva do STJ a respeito do assunto ${ }^{44}$.

Sem embargo, enquanto à justiça federal fica designado papel de decidir sobre a restituição ${ }^{45}$, fica a cargo da nossa justiça estadual tratar sobre o direito de guarda caso entendido ser o Brasil o local de residência habitual daquela criança, conforme já apontado neste trabalho.

Em todos os países, o poder judiciário intensificou seu aprendizado com a Convenção, amadurecendo suas decisões ao longo do tempo.

Esta crescente preocupação em refinar as decisões judiciais possui reflexos nítidos na questão envolvendo a produção de provas. Nota-se,

\footnotetext{
${ }^{43}$ Ementa: CONFLITO DE COMPETÊNCIA. JUSTIÇA ESTADUAL E JUSTIÇA FEDERAL. AÇÃO DE RECONHECIMENTO DE PATERNIDADE SOCIO-AFETIVA CUMULADA COM POSSE E GUARDA. AÇÃO DE BUSCA, APREENSÃO E RESTITUIÇÃO DE MENOR AJUIZADA PELA UNIÃO FEDERAL COM FUNDAMENTO NA CONVENÇÃO DE HAIA SOBRE OS ASPECTOS CIVIS DO SEQÜESTRO INTERNACIONAL DE CRIANÇAS. 1. A conexão afigura-se entre duas ou mais ações quando há entre elas identidade de objeto ou de causa de pedir, impondo a reunião das demandas para julgamento conjunto, evitando-se, assim, decisões contraditórias, o que acarretaria grave desprestígio para o Poder Judiciário. 2. Demonstrada a conexão entre a ação de busca, apreensão e restituição e a ação de reconhecimento de paternidade sócio-afetiva cumulada com posse e guarda, ambas com o mesmo objeto comum, qual seja, a guarda do menor, impõe-se a reunião dos processos para julgamento conjunto (arts. 115 -III, e 103 , CPC ), a fim de se evitar decisões conflitantes e incompatíveis entre si. 3. A presença da União Federal nas duas causas, em uma delas na condição de autora e na outra como assistente, torna imprescindível a reunião dos feitos perante a Justiça Federal, a teor do que dispõe o art. 109, I, da Constituição Federal . 4. Ademais, o objeto de uma das demandas é o cumprimento de obrigação fundada em tratado internacional (art. 109 , III , da Constituição Federal ). 5. Conflito conhecido, declarando-se competente o Juízo Federal da $16^{\mathrm{a}}$ Vara Cível da Seção Judiciária do Estado Rio de Janeiro, determinando-lhe a remessa pelo Juízo de Direito da $2^{\mathrm{a}}$ Vara de Família do Foro Central do Rio de Janeiro/RJ dos autos da ação de reconhecimento de paternidade sócio-afetiva.

${ }^{44}$ FILHO, Theophilo Antonio Miguel. Op. Cit, p. 111-112.
} 
neste sentido, uma grande fixação dos juízes no exame da prova, possuindo a situação fática um grande peso na decisão ${ }^{46}$.

É imperioso ressaltar que, por estarmos lidando com um direito indisponível, o Magistrado deve sempre objetivar pela busca da verdade real pois ele atua "como destinatário da prova, determinar a realização de todas as provas admissíveis com o fito de dirimir as incongruências e contradições" ${ }^{\prime 4}$.

Em igual sentido, seguindo jurisprudência pacífica, o Ministro Humberto Martins compreendeu que:

\begin{abstract}
"Para que se possa entender esse princípio (melhor interesse do menor), bem como para sua aplicação, o julgador deve considerar uma série de fatores, como o amor e os laços afetivos entre os pais, os familiares e a criança, o lar da criança, a escola, a comunidade, os laços religiosos e a habilidade do guardião de encorajar contato e comunicação saudável entre a criança e o outro genitor. Essas considerações, essencialmente subjetivas, são indicadores que conduzem o juiz à descoberta do que lhe parece ser o melhor interesse da criança em cada caso concreto. Por isso a Convenção da Haia, não obstante apresente reprimenda rigorosa ao sequestro internacional de menores, com determinação expressa de seu retorno ao país de origem, garante o bem estar e a integridade física e emocional da criança, o que deve ser avaliado de forma criteriosa, fazendo-se necessária a prova pericial psicológica". ${ }^{4}$
\end{abstract}

\footnotetext{
${ }^{46}$ Informativo do STJ n 525 - Período: 11 de setembro de 2013 (topo) Repatriação de Criança ou Adolescente, Convenção da Haia. Prova Pericial. Avaliação Psicológica do Menor Discute-se a aplicação da Convenção sobre os Aspectos Civis do Sequestro Internacional de Crianças (Convenção da Haia), promulgada no Brasil mediante o Dec. n. 3.413/2000. Trata-se, na origem, de ação de busca, apreensão e restituição ajuizada pela União contra a segunda recorrente, cidadã brasileira, com o propósito de compelir a entregar seu filho, primeiro recorrente, menor, nascido no estrangeiro e filho do ora assistente, cidadão estrangeiro, à autoridade central brasileira e, ato contínuo, à autoridade central estrangeira, para restituição. Postulam os recorrentes a anulação de todos os atos processuais praticados desde o julgamento antecipado da lide, a fim de que os autos retornem à primeira instância para a produção das provas, em especial a perícia psicológica. $\mathrm{O}$ Min. Relator observou que a Convenção da Haia, contundente na reprimenda ao sequestro e na determinação de retorno imediato do menor ilicitamente transferido, revela, de forma equilibrada, grande preocupação com o bem-estar deste, assegurando-lhe, sobretudo, o equilíbrio emocional e a integridade física. Consta dos autos uma única avaliação psicológica do menor, efetuada há mais de três anos, a partir de um único encontro entre a perita do juízo e a criança. A conclusão dessa avaliação não conduz à certeza de ausência de grave dano no retorno da criança ao estado estrangeiro. Assim, asseverou o Min. Relator, é imprescindível a realização da perícia psicológica requerida, pois o interesse do menor sobreleva qualquer outro. Diante dessa e de outras considerações, a Turma deu parcial provimento para anular os provimentos ordinários e determinar a realização apenas da perícia psicológica. REsp 1.239.777- PE, Rel. Min. Cesar Asfor Rocha, julgado em 12/4/2012.

47 Disponível em: 〈http://www.agu.gov.br/page/content/imprimir/id_conteudo/119651>. Acesso em: 18 mai. 2015.

${ }^{48}$ Disponível em: <http://www.tjij.jus.br/documents/10136/110217/cooperacaointernacional.pdf?v=1>. Acesso em 19 mai. 2015.
} 
Portanto, cabe ao juiz expandir sua análise para além dos aspectos mais visíveis do conflito utilizando-se de todos os meios para alcançar a verdade real ${ }^{49}$, devendo avaliar o maior conjunto de aspectos influentes em cada caso concreto.

Não se desconhece que ainda existam algumas situações controversas que geram divergências quanto à aplicação da Convenção. Dentre estas, as que talvez causem mais conflitos (teóricos e práticos) são as exceções à regra geral do retorno da criança, pois quando configuradas, o retorno não será concretizado.

A seguir, um estudo sobre as especificidades destas exceções.

\footnotetext{
${ }^{49}$ Ementa: DIREITOS CIVIL E PROCESSUAL CIVIL. INVESTIGAÇÃO DE PATERNIDADE. PROVA TESTEMUNHAL PRECÁRIA. PROVA GENÉTICA. DNA. NATUREZA DA DEMANDA. AÇÃO DE ESTADO. BUSCA DA VERDADE REAL. PRECLUSÃO. INSTRUÇÃO PROBATÓRIA. INOCORRÊNCIA PARA O JUIZ. PROCESSO CIVIL CONTEMPORÂNEO. CERCEAMENTO DE DEFESA. ART. 130, CPC. CARACTERIZAÇÃO. RECURSO PROVIDO. I - Tem o julgador iniciativa probatória quando presentes razões de ordem pública e igualitária, como, por exemplo, quando se esteja diante de causa que tenha por objeto direito indisponível (ações de estado), ou quando, em face das provas produzidas, se encontre em estado de perplexidade ou, ainda, quando haja significativa desproporção econômica ou sóciocultural entre as partes. II - Além das questões concernentes às condições da ação e aos pressupostos processuais, a cujo respeito há expressa imunização legal (CPC, art. 267, § $3^{\circ}$ ), a preclusão não alcança o juiz em se cuidando de instrução probatória. III - Pelo nosso sistema jurídico, é perfeitamente possível a produção de prova em instância recursal ordinária. IV - No campo probatório, a grande evolução jurídica em nosso século continua sendo, em termos processuais, a busca da verdade real. V - Diante do cada vez maior sentido publicista que se tem atribuído ao processo contemporâneo, o juiz deixou de ser mero espectador inerte da batalha judicial, passando a assumir posição ativa, que lhe permite, dentre outras prerrogativas, determinar a produção de provas, desde que o faça com imparcialidade e resguardando o princípio do contraditório. VI - Na fase atual da evolução do Direito de Família, não se justifica desprezar a produção da prova genética pelo DNA, que a ciência tem proclamado idônea e eficaz.
} 


\section{CAPÍTULO 2 - EXCEÇÕES À OBRIGAÇÃO DE RETORNO}

\subsection{Noções básicas sobre os Artigos 12 e 20}

Resta claro que a Convenção se fundamenta no retorno ao status quo anterior à retenção ou transferência da criança, imediatamente à configuração do ilícito. Diante disso, legitima, de forma excepcional, determinadas situações em que o Estado requerido não seria obrigado a ordenar que a criança retornasse ao país do qual foi retirada.

Ressalvas à ordem de retorno estão ordenadas nos artigos 12, 13 e 20, da Convenção.

A primeira exceção, firmada no Artigo 12, dispõe que a recusa pode ser feita caso haja transcorrido mais de um ano entre a data da transferência ou da retenção indevidas e o início do processo ${ }^{50}$. O objetivo é lidar com as situações nas quais, quando devidamente constatado, a criança já se adaptou ao novo meio, e que isso seria perfeitamente possível na margem temporal estabelecida pelo artigo.

Quando há a transferência ilícita, adota-se o posicionamento de que o termo inicial se dá no momento em que houve o ingresso da criança no país do Estado de refúgio ${ }^{51}$ ou, no caso de retenção, a data em que a criança deveria ter voltado ao local de sua residência habitual ${ }^{52}$.

\footnotetext{
${ }^{50}$ Artigo 12. Quando uma criança tiver sido ilicitamente transferida ou retida nos termos do Artigo 3 e tenha decorrido um período de menos de 1 ano entre a data da transferência ou da retenção indevidas e a data do início do processo perante a autoridade judicial ou administrativa do Estado Contratante onde a criança se encontrar, a autoridade respectiva deverá ordenar o retomo imediato da criança.

A autoridade judicial ou administrativa respectiva, mesmo após expirado o período de um ano referido no parágrafo anterior, deverá ordenar o retorno da criança, salvo quando for provado que a criança já se encontra integrada no seu novo meio.

Quando a autoridade judicial ou administrativa do Estado requerido tiver razões para crer que a criança tenha sido levada para outro Estado, poderá suspender o processo ou rejeitar o pedido para o retomo da criança.

${ }^{51}$ Discute-se ainda se o prazo poderia ser contado do momento da subtração, mas tal teoria pode ser descartada pela existência de situações em que o "taking parent" desloca-se com a criança por diversos lugares por um longo período de tempo até se estabelecerem em um determinado país,
} 
Outro problema é quanto à disposição do artigo sobre a "data do início do processo perante a autoridade judicial ou administrativa". Como sugerido pela autora Natalia Martins, a contatem do termo "ad quem" pode se dar da seguinte forma:

"Para fins deste dispositivo, deve-se entender como início do processo perante a autoridade judicial ou administrativa do estado contratante onde a criança se encontrar, a data do recebimento do pedido de cooperação jurídica internacional pela autoridade central do estado requerido. Nos casos em que não é utilizado o mecanismo de cooperação entre autoridades centrais - artigo 29 - o termo "ad quem" será a data de protocolização da petição inicial da ação de busca, apreensão e restituição da criança, diretamente pela pessoa interessada em sua restituição,"53.

Isto porque somente ao receber o pedido de cooperação a autoridade central poderá tomar providências referentes ao processo de conhecimento para solucionar o conflito, aumentando as chances de contato com o genitor abdutor e a criança, antes da perda do prazo ${ }^{54}$.

Portanto, nada se tem a discutir quando não houver passado o período de um ano, devendo a criança retornar de prontidão. Caso haja transcorrido este prazo, a criança deve ser retornada e, neste caso, com salvaguarda analisando-se a ocorrência ou não de integração da mesma ao novo meio.

A segunda possibilidade de denegação do retorno está prevista no Artigo 20, haja vista a incompatibilidade entre os direitos humanos e liberdades fundamentais e os princípios do Estado requerido ${ }^{55}$.

Tal dispositivo surgiu para proteger a criança do risco de sofrer abusos em razão do sistema jurídico do local para onde foi levada não

sendo este considerado o Estado de refúgio, que será demandando judicialmente, o que geraria uma complicação muito maior se tivéssemos o momento da abdução como marco inicial.

${ }^{52}$ MARTINS, Natalia Camba. Subtração Internacional de Crianças: as exceções à obrigação de retorno previstas na Convenção de Haia de 1980 sobre aspectos civis do sequestro internacional de crianças: interpretação judicial da adaptação da criança / Natalia Camba Martins. - 1. Ed. Curitiba, PR: CRV, 2013, p. 195.

${ }^{53}$ Ibid., p. 200.

${ }^{54} \mathrm{O}$ exame do Artigo 12 possui profundas discussões teóricas materiais sobre o início e a extensão do prazo, divergências sobre o termo "a quo" e "ad quem" que não serão analisadas, por não ser o foco do presente trabalho.

${ }^{55}$ Artigo 20. O retomo da criança de acordo com as disposições contidas no Artigo $12^{\circ}$ poderá ser recusado quando não for compatível com os princípios fundamentais do Estado requerido com relação à proteção dos direitos humanos e das liberdades fundamentais. 
proteger seus interesses, países cujos governos possuem laços autoritários fortes que restringem - ou até mesmo suprimem - os direitos individuais.

O objetivo é evitar a ameaça da descriminação, prostituição, trabalhos forçados, escravidão, ou quaisquer alternativas similares ${ }^{56}$.

Não é desconhecido o fato de que cada país é soberano para estipular suas próprias raízes e princípios basilares que compõem seu ordenamento, além da ética singular que define sua sociedade, podendo estes convergirem ou divergirem, ao serem comparados entre si pela comunidade internacional.

Isso dificulta qualquer tentativa de universalizar os princípios, o que faz com que o Artigo em questão carregue um enorme peso subjetivo. Ainda assim, a vocação ao artigo é feita somente em casos extremos, em que o retorno da criança afete fundamentalmente a percepção do Estado requerido sobre o que são direitos e liberdades fundamentais em contraposição ao Estado de onde criança foi levada.

Para tanto, a autoridade em questão (do país requerido) deve comprovar tanto comprovar a contradição, quanto a existência de princípios protetores de direitos humanos que proíbem o retorno solicitado, possibilitando negar o retorno da criança com base em argumentos puramente jurídicos, retirados do próprio direito interno do Estado requerido ${ }^{57}$.

\subsection{O Artigo 13 da Convenção}

A última exceção a ser analisada neste trabalho é, de longe, a que mais gera discussões e problemas práticos na sua aplicação.

\footnotetext{
${ }^{56}$ DE SOUSA, Mafalda Paulino Gomes. Convenção de Haia relativa ao rapto internacional de crianças: A noção de perigo do artigo 13 al. B) e o interesse da criança. Mestrado Forense. Faculdade de Direito da Universidade Católica Portuguesa. Lisboa, 2013, p. 13.

${ }^{57}$ PÉREZ-VERA, 1981, p. 8.
} 
O Artigo 13 faz referência à quatro outras hipóteses que preveem a permanência da criança no país para onde foi levada ${ }^{58}$.

A primeira delas é decorrente das "situações em que a pessoa, instituição ou organismo que tinha a seu cuidado a pessoa da criança não exercia efetivamente o direito de guarda na época da transferência ou da retenção" (Artigo 13, a, primeira parte).

De acordo com a própria Convenção, aquele que possui o direito de guarda da criança detém a responsabilidade de cuidar dela, de zelar por seu bem-estar físico, psicológico e educacional, e quem se opõe ao retorno vai ter que provar que o genitor abandonado não exercia o direito de guarda ${ }^{59}$. Por isso, admite-se como primeira hipótese do Artigo 13 que a criança permaneça no país requerido quando seu guardião efetivamente não cumpre

\footnotetext{
${ }^{58}$ Artigo 13. Sem prejuízo das disposições contidas no Artigo anterior, a autoridade judicial ou administrativa do Estado requerido não é obrigada a ordenar o retomo da criança se a pessoa, instituição ou organismo que se oponha a seu retomo provar: a) que a pessoa, instituição ou organismo que tinha a seu cuidado a pessoa da criança não exercia efetivamente o direito de guarda na época da transferência ou da retenção, ou que havia consentido ou concordado posteriormente com esta transferência ou retenção; ou b) que existe um risco grave de a criança, no seu retorno, ficar sujeita a perigos de ordem física ou psíquica, ou, de qualquer outro modo, ficar numa situação intolerável.

A autoridade judicial ou administrativa pode também recusar-se a ordenar o e retorno da criança se verificar que esta se opõe a ele e que a criança atingiu já idade e grau de maturidade tais que seja apropriado levar em consideração as suas opiniões sobre o assunto.

Ao apreciar as circunstâncias referidas neste Artigo, as autoridades judiciais ou administrativas deverão tomar em consideração as informações relativas à situação social da criança fornecidas pela Autoridade Central ou por qualquer outra autoridade competente do Estado de residência habitual da criança.

${ }^{59}$ Em seu livro, Natalia Camba aponta críticas referentes à adoção da literalidade ao texto do dispositivo "que tinha a seu cuidado a pessoa da criança" e a própria configuração da hipótese como exceção, afirmando que "caberá ao órgão julgador, em cada caso, determinar o caráter de efetividade (ou não) dos cuidados com a pessoa da criança. Relacionando este dispositivo com a definição de retenção e transferências ilícitas, vinculadas ao artigo $3^{\circ}$ do tratado, conclui0se que a comprovação de que os cuidados com a criança não eram efetivos não se trata, propriamente, de uma exceção à obrigação de retorno, apesar de mencionado no artigo 13 da Convenção. Em verdade, trata-se de requisito para a configuração da ilicitude na transferência ou retenção. Assim, caso verifique-se, num caso concreto, que o genitor abandonado não "exercia efetivamente" seu direito convencional de guarda, a conclusão será pela incoerência da subtração ilícita - e não pela aplicação da Convenção ao caso, com subsequente configuração da exceção à obrigação d e retorno".
} 
suas obrigações, podendo perder o direito de decidir sobre o local de sua residência ${ }^{60}$.

Segundo, "se havia consentido ou concordado posteriormente com esta transferência ou retenção" (Artigo 13, a, segunda parte), que ocorre quando, por exemplo, a pessoa que pediu o retorno omitiu que consentiu ou concordou (podendo ser de forma expressa ou tácita) com a mudança da residência para o outro país no momento da saída, ou posteriormente.

Terceiro, "se existir um risco grave de a criança, no seu retorno, ficar sujeita a perigos de ordem física ou psíquica, ou, de qualquer outro modo, ficar numa situação intolerável” (Artigo 13, alínea b), situação ícone no presente trabalho, taxado como o dispositivo mais controverso quanto aos conceitos teóricos embutidos e, ao mesmo tempo, mais utilizado ${ }^{61}$.

Reservamos o próximo capítulo deste trabalho para tratar mais a fundo sobre o tema.

Por fim, a quarta e última hipótese, alude o caso de a "autoridade central verificar que a criança se opõe ao retorno, que a criança atingiu já idade e grau de maturidade tais que seja apropriado levar em consideração as suas opiniões sobre o assunto" (Artigo 13, parágrafo $2^{\circ}$ ).

Neste caso, a ideia é que a criança seja ouvida de prontidão para evitar que sua opinião não seja dotada de vício (muitas vezes influenciada pelo próprio genitor abdutor), devendo, por este motivo, ser um dos primeiros atos a serem realizados pelo juiz, sendo absolutamente necessária

\footnotetext{
${ }^{60}$ Artigo 5. Nos termos da presente Convenção: a) o "direito de guarda" compreenderá os direitos relativos aos cuidados com a pessoa da criança, e, em particular, o direito de decidir sobre o lugar da sua residência; (...).

61 "Las excepciones previstas en la letra b se refieren a situaciones en las que la sustracción internacional de un menor ha tenido realmente lugar pero en las que su retorno sería contrario a su interés, tal y como se entiende en este subapartado. Cada uno de los términos utilizados en la disposición refleja el delicado compromiso alcanzado en el transcurso de los trabajos de la Comisión especial y que se mantuvo sin cambios; por consiguiente, no se pueden deducir, a contrario, interpretaciones extensivas del rechazo, durante el Decimocuarto período de sesiones, de propuestas encaminadas a incluir una referencia expresa a la imposibilidad de alegar esta excepción cuando el retorno del menor pudiera perjudicar sus perspectivas económicas o educativas" (PÉREZ-VERA, Explanatory Report, 1981)
} 
avaliação de equipe técnica especializada para terminar se a criança possui maturidade suficiente para ter sua opinião analisada ${ }^{62}$.

Enfim, é defendido por muitos autores e tradicionalmente assumido pelos países membros o posicionamento de que a aplicação destas exceções (Artigos 12, 13 e 20) deve ser feita de forma restritiva ${ }^{63}$, interpretação adotada pelo nosso ordenamento jurídico em casos anteriores ${ }^{64}$, já que as

${ }_{62}^{62}$ CAMBA, 2013, p. 165-166.

${ }^{63}$ PÉREZ-VERA, 1981, p. 9.

${ }^{64}$ PROCESSUAL CIVIL.CONVENÇÃO DA HAIA SOBRE "ASPECTOS CIVIS DO SEQUESTRO INTERNACIONAL DE CRIANÇAS". AÇÃO DE BUSCA, APREENSÃO E RESTITUIÇÃO DE MENOR. (...) IMPROPRIEDADE DA ANÁLISE DE ALEGAÇÕES DE NULIDADE DA SENTENÇA, POR OCORRÊNCIA DE CERCEAMENTO DE DEFESA E IMPRESTABILIDADE DO LAUDO PERICIAL. (...) RECONHECIMENTO DA OCORRÊNCIA DE RETENÇÃO ILÍCITA. EXCEÇÕES NÃO CONFIGURADAS. (...) Hipótese em que restou comprovado nos autos que o menor S.R.G. mantinha residência habitual no Estado de Nova Jérsei, USA, até 16 de junho de 2004, e que seu pai detinha o respectivo direito de guarda. Com a vinda do infante para o Brasil, em férias, na companhia de sua mãe, e conseqüente permanência desautorizada, evidenciou-se violação a normas da Convenção e da respectiva lei americana de regência. A isso se seguiu uma segunda retenção de Sean, não menos ilícita, já então perpetrada pelo apelante, em conseqüência da morte da genitora. Ambas retenções deram ensejo ao ajuizamanto de ações distintas, com base em que a permanência do infate encontrava-se viciada na sua origem e que, destarte, a residência habitual do menor jamais poderia ser tida por fixada no Brasil. (...) - A exceção prevista no artigo 13, alínea "b", da Convenção da Haia de 1980, que trata da possibilidade da existência de grave risco de que a criança fique exposta a dano físico ou psicológico se devolvida ao Estado de sua residência habitual, deve ser interpretada restritivamente, sendo necessário evitar a devolução de infantes a famílias desestabilizadas, a ambientes sociais ou nacionais perigosos, países em convulsão, inter alia. Daí se extrai que tal previsão concerne a situações de fato caóticas, verificadas no domínio do Estado requerente, no que se poderiam enquadrar, de forma exemplificativa, hipóteses de conflitos armados, epidemias incontroláveis, rigoroso desabastecimento de alimentos, enfim, conjunturas que escapassem ao controle das próprias autoridades competentes do Estado de residência habitual da criança, situação em que, de certo, não se enquadram os EUA. - A aplicabilidade da exceção prevista no artigo 13, alínea "b", primeiro parágrafo, da Convenção da Haia de 1980, está condicionada a verificação de que a criança tenha atingido idade e grau de maturidade capazes de possibilitar que sua opinião seja levada em consideração, situação que não se verifica in casu, onde, como clara e enfaticamente externado no teor do laudo pericial pscicológico elaborado pelas peritas do Juízo, o menor S.R.G. não está apto a decidir sobre o que realmente deseja, seja pelas limitações de maturidade inerentes à sua tenra idade, seja pela fragilidade de seu estado emocional, seja, ainda, pelo fato de já estar submetido a processo de alienação parental por parte da família brasileira.

(APELAÇÃO CIVIL 2009.51.01.018422-0 TRF 2a Região, $5^{\text {a }}$ Turma Especializada, Data do Julgamento: 16/12/2009, Relator(a) DESEMBARGADOR FEDERAL FERNANDO MARQUES)

SEQUESTRO INTERNACIONAL DE MENORES. CONVENÇÃO DE HAIA. APLICABILIDADE. PRELIMINAR DE CERCEAMENTO DE DEFESA AFASTADA. I - Na ação de busca e apreensão de menores "sequestrados" internacionalmente, limita-se o magistrado a decidir quanto à aplicabilidade ou não à hipótese sob sua análise das normas da Convenção sobre os Aspectos Civis do Sequestro Internacional de Crianças, concluída na cidade de Haia, em 25 de outubro de 1980, e da qual o Brasil é signatário, cujo art. $1^{\circ}$ prevê, dentre seus objetivos, o de "assegurar o retorno imediato de crianças ilicitamente transferidas para qualquer Estado Contratante ou nele retidas indevidamente". Neste sentido, questionamentos sobre os sentimentos e impressões dos menores em relação ao genitor de quem se afastaram, bem como sobre a possível alienação parental a que estejam submetidos por força de possíveis manipulações exercidas pelo 
regras da Convenção são, além de tudo, baseadas na confiança entre os seus

membros, e que a utilização das mesmas ao bel-prazer singular de cada um

geraria grande insegurança jurídica, afetando o diálogo que tão

insistentemente se almeja.

outro genitor, a partir de versões unilaterais dos fatos, dentre outros, questionamentos que em tese, seriam considerados em laudo pericial elaborado por profissionais da área de psicologia, pouca relevância assumem para a solução da lide em questão, que se limita ao exame dos aspectos da possível ilegalidade da transferência das crianças de seu país de origem e residência habitual. Quanto às matérias que dizem respeito à guarda dos menores, deverão ser apreciadas pelo juiz competente para tal definição, qual seja, o juiz competente do local da residência habitual dos menores. Assim sendo, o indeferimento da prova pericial de natureza psicológica que objetiva avaliar o comprometimento psicológico dos menores em razão de sua transferência do país de origem e retenção no território brasileiro não consubstancia cerceamento de defesa apto a tornar nula a sentença apelada. II - Nos termos do art. $3^{\circ}$, "b", da Convenção de Haia: "A transferência ou a retenção de uma criança é considerada ilícita quando: (...) b) esse direito estivesse sendo exercido de maneira efetiva, individual ou conjuntamente, no momento da transferência ou da retenção, ou devesse estar sendo se tais acontecimentos não tiverem ocorrido." III - Da literalidade do artigo 12 da Convenção de Haia ressalta a preocupação dos Estados Contratantes em garantir a maior celeridade possível ao repatriamento das crianças ilegalmente transferidas de seu país de origem, com vistas a evitar ao máximo os malefícios inerentes a um retorno que somente viesse a ocorrer após a possivelmente árdua adaptação das crianças ao seu novo meio social. Entretanto, se comprovado que as medidas adotadas pelo genitor dos menores objetivando o retorno dos filhos ao seu país natal se iniciaram dentro do prazo de um ano previsto no referido artigo, não há que se falar em recusa ao repatriamento "em razão de estar integrada a criança ao seu novo meio". IVPor se tratar de uma exceção à regra geral, o art. 13, "b" da Convenção de Haia, segundo o qual a autoridade judicial do Estado requerido não está obrigada a ordenar o retorno da criança ilegalmente subtraída de seu país de origem quando restar provado que "existe um risco grave de a criança, no seu retorno, ficar sujeita a perigos de ordem física ou psíquica, ou de qualquer outro modo, ficar numa situação intolerável", deve ser interpretado restritivamente, pois a intenção dos Estados Contratantes teria sido, visando ao bem-estar do menor, apenas o de protegê-lo de perigos concretos a que pudesse expô-lo o seu retorno ao país de origem, tais como guerras civis, epidemias fora de controle, escassez de alimentos, e situações que evidenciassem uma falta de civilidade no âmbito do Estado requerente. Neste sentido, não poderia uma desavença entre o casal, ainda que grave, servir de fundamento para a aplicação da exceção ali prevista, mormente quando não comprovado o comprometimento da integridade física ou mental dos menores. V - Em se tratando de pedidos de cooperação jurídica internacional, aplica- se plenamente o princípio da reciprocidade entre os Estados contratantes, pelo que, segundo se espera, o tratamento dispensado pelo Brasil aos casos judiciais; envolvendo estrangeiros ilicitamente transferidos para este país será certamente retribuído no que tange aos nossos nacionais que aguardam repatriação. VI Apelação e remessa necessária providas. (APELAÇÃO CIVIL 2004.50.01.005578-3 TRF $2^{\mathrm{a}}$ Região, $8^{\text {a }}$ Turma Especializada, Data do Julgamento: 04/08/2009, Relator(a) JUIZ CONVOC. MARCELO PEREIRA DA SILVA NO AFAST. DO RELATOR) 


\section{CAPÍTULO 3 - O ARTIGO 13, ALÍNEA B, DA CONVENÇÃO}

\subsection{Risco grave de perigos de ordem física e psíquica e situação intolerável}

O Artigo 13, alínea b, apresenta três condições que dizem respeito à possíveis condições em que a criança possa se encontrar: "risco grave de perigos de ordem física", "risco grave de perigos de ordem psíquica" e "risco grave" decorrente de uma "situação intolerável".

São diversas as razões pelas quais as condições contidas neste artigo são alegadas em peso pelo "taking parent". Dentre elas, a notável falta de clareza da Convenção sobre o significado da expressão "grave risco de perigo" ou "situação intolerável" proporciona uma lacuna muito ampla e frouxa fazendo com que a aplicação da exceção se dê muitas vezes de modo discricionário pelos Estados-membros ${ }^{65}$.

Em seu Relatório Explicativo, Perez-Vera explica que a exceção envolvendo "grave risco" é baseada no reconhecimento de que o interesse do menor a não ser removido de sua residência habitual sem garantias suficientes de a nova será estável, em vista ao interesse primário de qualquer pessoa a não ser exposta perigos de ordem física ou psíquica, ou de ser inserida em uma situação intolerável ${ }^{66}$.

No entanto, nem a Convenção ou o Relatório Explicativo definem o que constitui "grave risco", cabendo à interpretação casuísticas dos juízes sobre o tema, o que resulta em decisões que se espraiam para todos os $\operatorname{lados}^{67}$.

\footnotetext{
${ }^{65}$ MORLEY, Jeremy. The Hague Abduction Convention: practical issues and procedures for Family lawyers, Chicago, IL: ABA (American Bar Association), 2012, p. 156.

${ }^{66}$ PEREZ-VERA, 1981, p. 7.

${ }^{67}$ "Em sentido contrário, encontramos a jurisprudência francesa, que tem interpretado, recentemente, o artigo $13^{\circ}, 1$, al. b), de uma forma que admite o não regresso da criança com maior amplitude. Isto é, existe uma recusa por parte da jurisprudência francesa de interpretar este preceito de forma restritiva. O conceito de perigo é aferido, assim, não só pelos danos que possam ser causados à criança pelas novas condições de vida encontradas junto do progenitor cujo direito foi violado, mas também pelos danos criados à estabilidade da vida da criança por
} 
Neste sentido, afirma Mafalda Paulino Gomes de Souza, em sua tese de mestrado sobre o tema:

"Existe uma insistência, por parte da jurisprudência, de que este risco deve resultar de um perigo imputável ao progenitor cujo direito foi violado e que procura a restituição da criança. Para além de exigirem prova dos riscos inadmissíveis a que a criança estaria exposta ao regressar ao estado requerente, existem ainda decisões que exigem que se comprove que as autoridades requerentes não tutelariam o bem-estar da criança. Outras, porém, limitam-se a referir que o interesse da criança será tutelado pelo estado requerente, sem no entanto existirem quaisquer garantias dessa tutela (...). As autoridades demonstram-se cautelosas no que respeita à objecção prevista no $\operatorname{artigo~} 13 .^{\circ} \mathrm{n} .{ }^{\circ} 1$ alínea b), devido ao entendimento restritivo que é dado aos conceitos indeterminados previstos no preceito. Nesse sentido, mesmo quando estão perante uma situação na qual é invocado artigo $13^{\circ} \mathrm{n}^{\circ} 1 \mathrm{al}$. b), e tudo indicia uma decisão para recusar o regresso, este é na mesma ordenado, se o estado requerente implementar medidas de segurança e de proteção" ${ }^{\text {"68 }}$.

\section{O posicionamento tradicionalmente adotado pelos Estados-} membros em interpretar restritivamente ${ }^{69}$ o escopo o Artigo 13.b atribui um valor muito alto à questão da prova, que deve ser efetiva a comprovar o dano sofrido pela criança no país de sua residência habitual ${ }^{70}$.

um nova alteração das condições de vida actuais desta, ou seja, pelas consequências provocadas pela separação da sua pessoa de referência"

Ibidem.

${ }^{68}$ DE SOUSA, 2013, p. 17.

${ }^{69 " ' O}$ ingresso, pelo Estado de refúgio, em discussões aprofundadas quanto à veracidade da alegação de abuso, transforma um caso de subtração internacional de crianças fundado na Convenção de Haia de 1980 num procedimento em que se discute a guarda da criança, evidenciando uma falta de confiança nas autoridades do Estado de residência habitual quanto à proteção da criança. De outro lado, a decisão de não restituição da criança reflete a obrigação do Estado de refúgio de não colocar a criança num ambiente inseguro. $O$ alcance de tal equilíbrio não é questão fácil. No entanto, a teoria nota, com pesar, o fato de as cortes dos Estados de refúgio continuarem a encontrar "razões" para obstar a restituição de crianças aos seus países de residência habitual (...). A aplicação, sempre restritiva, da exceção do artigo 13, parágrafo $1^{\circ}$, alínea $b$ a um caso concreto, portanto, deve ocorrer somente quando, para além da cabal comprovação da ocorrência de algum de seus elementos (risco grave de a criança ficar sujeita, em seu retorno, a perigos de ordem física, psíquica ou, de qualquer outro modo, ficar em situação intolerável), for constatado que o Estado de residência habitual não tomará (por impossibilidade ou ausência de interesse) todas as medidas necessárias ao afastamento do risco grave, protegendo integralmente a criança"

CAMBA, Nathalia, 2013, p. 141.

${ }^{70}$ Nos EUA, algumas cortes tem adotado um posicionamento resitrivo quanto à admissibilidade de material probatório, como é possível verificar no caso In re Coffield em que a Corte de Apelação de Ohio determinou que a prova testemunhal quanto à vida que a criança leva no país de refúgio seria irrelevante para a aplicação do Artigo 13.b. A Corte Superior no mesmo caso entendeu que a prova referente à como a mãe criara a criança antes da abdução seria uma prova a ser levada a questão de guarda, e não a uma situação concernente à Convenção de Haia. Em Tahan v. 
É mister esclarecer que quem deve provar o encaixe da exceção ao caso concreto é a pessoa que se opõe ao retorno, tão somente.

O problema da falta clareza e a questão probatória trazem à cooperação - entre os órgãos julgadores do Estado requerente e do Estado de refúgio - uma importância muito maior, podendo a autoridade central do segundo requerer esclarecimentos quanto ao caso, ou ao juízo do primeiro se informar sobre quais as medidas protetivas voltadas para a criança que estejam sendo ou serão tomadas ${ }^{71}$.

Em diversas situações de sequestro é possível verificar alegações de que a criança estaria sofrendo "perigos de ordem física" e "de ordem psíquica", muitas delas direcionadas, por exemplo, ao abuso sexual, retorno às zonas de guerra, fome e trabalho escravo.

Quanto ao "grave risco de ordem psíquica", tem-se adotado uma leitura bastante cuidadosa, em função de sua "natureza intangível e subjetiva" que "oferece uma grande oportunidade ao sequestrador que deseja impedir o retorno da criança ao país de residência habitual". Ao contrário dos perigos físicos, de visualização e quantificação perceptíveis ${ }^{72}$.

É comumente utilizado o argumento do perigo psicológico pelo "taking parent" como resultado de seu afastamento da criança, ou seja, ele se opõe ao retorno da criança afirmando que isso causaria um grave risco psicológico por ser separada dele.

Tal situação não possui resposta uniforme. Em alguns $\operatorname{casos}^{73}$, como ocorridos no Canadá e na Inglaterra, podemos verificar a jurisprudência se direcionando para uma interpretação restritiva de "perigo

Duquette, a petição requerendo oportunidade de apresentar evidencias quanto aos "sonhos e desejos, pesadelos e medos" da criança foi igualmente rejeitado.

In MORLEY, Jeremy, p. 159.

${ }^{71}$ CAMBA, Nathalia, 2013, p. 141.

${ }^{72}$ Ibid., p. 142.

${ }^{73}$ Exemplos de alguns casos estrangeiros neste sentido, encontrados na plataforma do INCADAT: decisão do Tribunal federal, na Suíça, de 15 de Novembro de 2005 [INCADAT: HC/E/CH 841]; decisão do Hoge Raad da Holanda, de 14 de Abril de 2000 [INCADAT: HC/E/NL 316]; decisão do Court of Appeal, em Inglaterra, de 14 de Dezembro de 1988 [INCADAT: HC/E/UK 34]. 
de ordem psíquica" afim de afastar a alegação (e decretar a restituição) em nome do princípio do melhor interesse do menor, que deve prevalecer ao interesse do genitor abdutor ${ }^{74}$.

Em outros casos, pode-se verificar uma interpretação ampla deste conceito feita pelos juízes, em aceitar o requerimento feito pelo genitor abdutor em não retornar a criança, como visto nas cortes Alemãs e Austríacas $^{75}$.

Por fim, a definição de "situação intolerável" resulta em tantas confusões conceituais quanto às duas outras expressões inseridas no referido artigo. Alegações envolvendo problemas de abusos sexuais, condições materiais do país de onde foi abduzida ou quanto ao seu sistema legal já foram apontadas como passíveis de serem enquadradas neste contexto.

Nos EUA, por exemplo, algumas cortes americanas geralmente ignoram a expressão, escolhendo analisar os casos com base no contexto de "grave risco". Outras, aplicam a teoria de que ambas as expressões constituiriam elementos correspondentes, teoria amplamente criticada por doutrinadores do local $^{76}$.

Contudo, o Departamento do Estado Americano limitou a expressão a fim de entendê-la, por exemplo, na situação em que há violência sexual pelo genitor que detém a custódia da criança, podendo denegar o retorno da mesma mediante comprovação do risco ${ }^{77}$.

Com isso, o mínimo que se pode dizer é que "situação intolerável" deve compreender, necessariamente, acontecimentos na vida da criança que não podem ser admitidas ou transigentes.

\footnotetext{
${ }^{74}$ DE SOUZA, 2013, p. 25.

75 Idem, p. 144.

${ }^{76}$ MORLEY, Jeremy, 2012, p. 192.

${ }^{77}$ Ibid, p. 193.
} 
A existência de lacunas tão amplas dificulta a efetividade da aplicação das exceções da Convenção de Haia de 1980, e a multiplicidade de interpretações existentes podem abalar o núcleo da cooperação internacional entre os Estados-membros: a confiança.

Destarte, diante das complicações quanto aos conceitos indeterminados que insurgem em problemas práticos, clara se mostra a necessidade de uma interpretação uniforme da Convenção, de uma abordagem transnacional, que só pode ser alcançada pelo encontro dos Estados-membros dispostos a convergir em sentidos e contextos baseados em suas experiências pessoais e estudos técnicos.

Após a devida contextualização, seguiremos para uma questão levantada sob o suporte do Artigo 13, alínea b, que vem causando enormes complicações no âmbito internacional e no Brasil: a violência doméstica como fundamento do sequestro internacional de menores.

\subsection{A problemática da violência doméstica nos casos de subtração internacional de menores}

Casos de sequestro internacional de menores envolvendo violência doméstica vêm ganhando protagonismo nos últimos anos. Quando elaborada, a Convenção de Haia de 1980 não incluiu nas suas previsões situações deste porte.

Em um contexto global de composições diferenciadas de famílias e uma maior facilidade de locomoção, além da comum busca por uma vida melhor em outro país, poucas pessoas, ou sequer, ninguém, imagina de pronto ser vítima de algum tipo de abuso.

Sabemos que quando se trata de abuso sexual sofrido diretamente pela criança, não há o que se discutir. É claramente uma das situações extremas que impossibilitam o retorno protegidas pela Convenção. 
O que se tem discutido são os casos nos quais a violência é vivenciada por um dos genitores (geralmente a mulher) que, aterrorizada com a possibilidade de o mesmo acontecer com seu rebento, foge do país para se livrar dos tratos abusivos do pai violentador e retorna ao Brasil, em busca de proteção para si e seus filhos.

Não há consenso mundial de que a violência contra a mulher seja motivo para a aplicação deste artigo, como veremos no último tópico ao analisar as jurisprudências de diversos órgãos judiciais. Isto porque a maior parte dos países faz uma leitura de que o artigo se limitaria a criança como vítima direta do abuso, e que o juiz da residência habitual deveria ser responsável pela investigação e apuração do contexto da violência.

Ora, se engessarmos este entendimento de que para que se configure a exceção seja necessário que a violência ocorra diretamente com a criança, excluindo aquela sofrida pela mulher, podemos facilmente enxergar um cenário em que a mesma permanece em um ambiente abusivo e violento para o resto da vida por saber que se tentar sair do país a criança será devolvida e poderá sofrer com os mesmos traumas, o que nada mais resultaria em uma revitimização da mulher, duplamente condenada ao sofrimento (por si e por seus filhos).

A persistência em uma interpretação restritiva ${ }^{78}$ das expressões contidas no Artigo 13, alínea b, nestes casos, dificulta sua aplicação, salvo situações em que o genitor abdutor é capaz de provar cabalmente uma ligação incontroversa entre o abuso conjugal e o risco que isso poderia gerar à criança ${ }^{79}$, o que por si já se mostra minimamente protetiva.

\footnotetext{
78 " A interpretação restritiva sugere que "risco grave" e "situação intolerável" estão relacionados a circunstâncias envolvendo guerras, fome e outras catástrofes que possam colocar a criança em perigo de morte, ou, ainda, que envolvam sério risco de abuso ou negligência para as quais os tribunais do país de residência habitual se mostrem incapazes de oferecer proteção adequada". Em MAZZUOLI, Valério de Oliveira; MATTOS, Elsa de. Sequestro internacional de criança fundado em violência doméstica perpetrada no país de residência: a importância da perícia psicológica como garantia do melhor interesse da criança. Revista dos Tribunais, vol. 954 (2015), p. 239-254.

${ }^{79}$ MORLEY, Jeremy, p. 187.
} 
Uma interpretação literal da Convenção, em um contexto de violência doméstica, pode gerar injustiças e resultados reversos àqueles preteridos pela mesma, de proteção integral da criança.

Neste sentido, Nathalia Camba:

"Além disso, outros estudos, de natureza social, concluem que abusadores de esposas podem tornar-se abusadores de criança, sendo que aumentam as chances de risco de danos físicos e psíquicos a ela quando esta estiver em contato recorrente com um abusador de esposa. Reconhece-se que os órgãos julgadores podem interpretar as disposições da Convenção de Haia de 1980 de modo a conferir maior proteção às vítimas de violência doméstica e suas crianças".

Assim, devido ao problema anteriormente discutido da falta de uniformidade nos conceitos, na prática, os órgãos julgadores vêm se posicionando de acordo com seu direito interno, o que não seria o desfecho mais adequado em um contexto envolvendo um tratado internacional.

Neste mesmo sentido, considerando-se a adoção de uma leitura estática do artigo 13, alínea b, é possível afirmar que "o remédio de retorno funciona bem quando o abdutor é o genitor que não detém a custódia da criança", se mostrando falho em situações em que "o abdutor é o cuidador primário que está tentando proteger a si mesmo e às crianças contra a violência praticada pelo outro genitor ${ }^{\prime \prime 80}$.

Por isso, o autor e professor Valério de Oliveira Mazzuoli insiste em um olhar amplo aos conceitos deste artigo:

"Uma definição ampliada do que consiste "risco grave" e "situação intolerável", nesses casos, é necessária, pois atende ao melhor interesse da criança e pode impedir que mães que já sofreram violência no passado sejam revitimizadas e obrigadas a devolver seus filhos para genitores abusivos em países que não foram capazes de lhes oferecer proteção adequada, pelo menos temporariamente, enquanto não se resolvem essas questões nos juízos locais" ${ }^{\text {" } 11}$.

\footnotetext{
${ }^{80}$ WEINER, Merle H. Navigating the road between uniformity and progress: the need for purposive analysis of the Hague Convention on the Civil Aspects of International Child Abduction. Columbia Human Rights Law Review, vol. 33 (2002), p. 275-279 apud MAZZUOLI, Valério de Oliveira; MATTOS, Elsa de. Op. cit, p. 244.

${ }^{81}$ Ibid, p. 246.
} 
Estudos realizados neste campo, em diversos países, já demonstraram que a convivência de crianças com a violência doméstica sofrida pelo genitor pode repercutir nestas crianças igualmente sofrerem atos violentos ${ }^{82}$. Isto porque, alguém que mostra comportamento violento com outra pessoa está propenso a ter o mesmo comportamento com quem quer que seja.

Transferindo esta conjuntura para o nosso sistema, na falta objetividade e respostas não oferecidas pela Convenção, acompanhando a prática de todos os Estados-membros, nossa legislação interna pode acalmar esta inquietação.

Em 2006 foi promulgada a Lei $n^{\circ}$ 11.340/2006 (Lei Maria da Penha), criando mecanismos para coibir a violência doméstica e familiar contra a mulher que, pode ser visto como instrumento reforçador da Convenção na proteção analógica dos casos de sequestro internacional de menores, presentes, por óbvio, as condições probatórias necessárias.

Nesta mesma linha, Rodrigo F. More, consultor pro bono da Secretaria de Políticas para Mulheres da Presidência da República para a Convenção de Haia de 1980 sobre os Aspectos Civis do Sequestro Internacional de Crianças, em seu artigo, confirma o pensamento de uma nova interpretação da exceção:

\begin{abstract}
“Assim, após a Lei Maria da Penha (2006) a Convenção de Haia de 1980 deveria passar a ser interpretada num contexto ampliado não apenas em relação aos dispositivos de proteção às crianças previstos na própria Convenção, mas num contexto mais amplo e verticalizado de respeito a direitos humanos, de proteção à mulher contra a violência doméstica e familiar, da assistência a mães
\end{abstract}

\footnotetext{
82 "Diversos estudos compilados por Shetty e Edleson, realizados com crianças que convivem com a violência doméstica, apontam que, muitas vezes, elas também se tornam vítimas das agressões físicas ou psicológicas proferidas por um genitor contra o outro. As pesquisas apontam para a ocorrência simultânea da violência interparental e da violência ou maus tratos contra a criança. Nesse sentido, as crianças expostas à violência doméstica estão potencialmente sob "risco grave" de se tornarem vítimas, elas próprias, dessa violência. Tais aspectos, portanto, devem ser investigados em profundidade antes de qualquer tomada de decisão quanto ao retorno da criança ao país de residência habitual (...).

SHETTY, Sudha; EDLESON, Jefferson L. Adult domestic violence in cases of international parental child abduction cit., p. 115-138. apud MAZZUOLI, Valério de Oliveira; MATTOS, Elsa de. Op. cit, p. 246.
} 
brasileiras que, de vítimas, passaram a ser acusadas de "sequestro" dos próprios filhos" 83 .

Seria ilógico, portanto, que se retorne uma criança para uma situação de risco grave de ordem física, psíquica ou situação intolerável à vista de uma interpretação limitada à conceitos indeterminados quando presente instrumentos internos compatíveis que possam iluminar os caminhos tortuosos ainda problemáticos da Convenção.

Em vista à maioria dos casos passivos de mulheres retornando com crianças para o Brasil, desde 2010, por meio da ouvidoria da Secretaria de Políticas para as Mulheres (SPM) ${ }^{84}$ com parceria da Autoridade Central da Administração Federal (ACAF/SDH) ${ }^{85}$, o Brasil tem recebido pedidos de mulheres em situação de vulnerabilidade, vítimas de violência no exterior por seus cônjuges/companheiros, que voltaram ao país com seus filhos, sendo assim processadas pela retenção ilícita destes. Estes órgãos são responsáveis pelo auxílio destas mulheres a fim que se caracterize a aplicação da exceção do artigo 13, alínea b, ao caso, defendendo-as e buscando comprovar os indícios de violência ${ }^{86}$.

Enfim, seguiremos com a exposição de casos em tribunais diversos cujas decisões irradiam a fim de preencher as lacunas conceituais existentes apresentadas.

\footnotetext{
${ }^{83}$ MORE, Rodrigo F. A violência doméstica e familiar contra a Mulher e o sequestro internacional de crianças: Estudos de casos e medidas urgentes. Revista Estudos Jurídicos UNESP, Franca, A. 14 n.20, 2010, p. 290.

${ }^{84}$ A Secretaria de Política para Mulheres, foi criada pela Medida Provisória n ${ }^{\circ}$ 103, de 1/01/2003, convertida na Lei $\mathrm{n}^{\circ} 10.683$, de 28/05/2003 (DOU 29/05/2003).

${ }^{85}$ A ACAF é o órgão central responsável pela implementação da Convenção de Haia de 1980 sobre Sequestro Internacional de Menores no Brasil, atuando conjuntamente com a AdvocaciaGeral da União, que possui papel central no processo, cuja missão é promover a cooperação jurídica internacional direta para a implementação da Convenção. A Comissão Permanente da ACAF tem como um de seus objetivos "propor procedimentos administrativos conjuntos a serem adotados em casos em que houver alegação de ocorrência de violência doméstica contra a mulher, bem como contra criança e adolescente", vide capitulo 1 deste trabalho.

${ }^{86}$ MAZZUOLI, 2015, p. 248.
} 


\title{
3.3. Análise de jurisprudência
}

\begin{abstract}
Algumas cortes de muitos Estados-membros já vêm se posicionando a favor de uma interpretação cada vez mais ampla dos conceitos de "grave risco de ordem física", "de ordem psíquica" e "situação intolerável”.
\end{abstract}

A Suprema Corte Inglesa adotou alguns princípios para aparar as arestas dos conceitos acima. Em exame, afirma que o risco do menor deve alcançar um nível de seriedade suficiente a ser principalmente "grave” não bastando ser apenas "real" 88 .

Por "situação intolerável" compreende se tratar de uma situação que, aquela criança em particular, nas circunstancias apresentadas e ordenadas como assim foram, não deveriam ser aceitas e nem esperadas como "toleráveis" pelo menor ${ }^{89}$.

Apontou, ainda, de que a aplicação do artigo 13, alínea b, é linear e indissolúvel à aplicação de medidas protetivas, ou seja, a situação de retorno dependerá de o Estado requerido colocar em prática tais medidas a

\footnotetext{
${ }^{87}$ Outros casos que definiram as expressões de "grave risco":

"Article 13(b) names three risks, interlinked by the use of the word "otherwise". The proper course for the court when considering an Article 13(1)(b) defence is to consider the grave risk of harm as a discrete question and then consider the Article in the round, asking if the risk of harm was established to the extent that led one to say that the child would be placed in an intolerable situation if returned: $\operatorname{Re} S$ (A Child) [2002] EWCA Civ 908.

Re H (Children)(Abduction: Grave Risk) [2003] EWCA 355: the threshold that had to be crossed when an Article 13(b) defence was raised was a high one and difficult to surmount. Even if the threshold was crossed the court retained a discretion as to whether to return the child.

TB v JB (Abduction: Grave Risk of Harm) [2001] 2 FLR 515: where fear of violence from the applicant is alleged as a basis to establish grave risk of psychological harm to the children, the court will take into account measures which the alleging party could reasonably be expected to take in the requesting country to protect herself and her children against the applicant.

Re B (Abduction: Grave Risk) [2005] EWHC 2988 (Fam): where it is alleged that the applicant has breached conditions attached to an order made by a court in the requesting state, the proper course should be to return the children for that court to consider the issues raised on a renewed application."

Disponível em: <http://www.international-divorce.com/New_Case_Law_in_England.htm>. Acesso em: 25/10/15

${ }^{88}$ Re. E, [2011] UKSC 27, [2011] FLR 758, In MORLY, Jeremy, p. 168.

${ }^{89}$ Disponível em: <http://www.international-divorce.com/New_Case_Law_in_England.htm>. Acesso em: 25/10/15
} 
fim de o menor não tenha que vivenciar quaisquer situações intoleráveis quando voltar para sua residência habitual ${ }^{90}$.

É perceptível a posição tradicional de interpretação adotada pelo Reino Unido, em razão da extensão da primazia de quem detém a competência para tratar do retorno, que é do país da residência habitual, por possuírem melhores condições em avaliar o perigo ("risco grave") e dar proteção, situação que não seria inteiramente possível ao se atribuir uma compreensão ampla das expressões contidas no artigo $^{91}$.

Nos EUA, o paradigmático caso Friedrich v. Friedrich, em decisão do $6^{\circ}$ Circuito da Corte de Apelação, apresenta o posicionamento tradicional de que "grave risco de perigo" não deve atender a um "evento futuro e hipotético", mas sim, ser atribuído em duas situações: 1) quando há perigo iminente no retorno devendo-se aguardar até que a disputa quanto ao direito de guarda seja decidido (por exemplo, retornar a criança a uma zona de guerra, fome ou doença); 2) nos casos de sério abuso, negligência, ou extraordinária dependência emocional, em se reconhecendo que os órgãos julgadores do Estado de residência habitual "sejam incapazes ou não dispostos a conceder à criança proteção adequada" ${ }^{\prime 92}$.

Quanto à especificidade da violência doméstica, em Walsh vs. Walsh (First Circuit, EUA, 2000), caso em que o pai era acusado de violentar a mãe, pela demonstração do temperamento violento do pai mesmo na presença das crianças, com o apoio de doutrinas que afirmavam que cônjuges abusivos possuem a tendência de igual violência para com seus filhos, foi reconhecido que os menores correriam um alto risco psicológico quando em constante contato com um pai abusivo. Assim, houve o reconhecimento de que o testemunho das crianças à violência

\footnotetext{
${ }^{90}$ Disponível em: <http://www.international-divorce.com/New_Case_Law_in_England.htm>. Acesso em: 26/10/15.

${ }^{91}$ CAMBA, 2013, p. 136.

${ }^{92}$ Ibid., p. 137 .
} 
doméstica conjugal pode ser um limiar criador de "risco grave de ordem física" (grave risk of harm) ${ }^{93}$.

Igualmente, em 2001, o Tribunal Federal do Estado de Washington reconheceu, no caso Tsarbopoulos vs. Tsarbopoulos ${ }^{94}$, que a violência doméstica sofrida pelo cônjuge pode ser fator determinante para caracterizar a aplicação da exceção do Artigo 13, alínea b, no contexto de "risco grave de ordem psicológica", pelo potencial que um violentador de mulheres pode ter a abusar de menores.

A abrangência do conceito de "grave risco de dano" se mostra mais clara ainda, quando em dois $\operatorname{casos}^{95}$ de sequestro no aspecto passivo, ou seja, situações em que as mães fogem para os EUA com seus filhos alegando terem sofrido abuso sexual pelo cônjuge, o Tribunal Federal do Estado de Nova York negou de prontidão o pedido de retorno em razão do "grave risco de dano" que tal retorno implicaria para as crianças.

Outros casos semelhantes de cortes $\operatorname{americanas}^{96}$, os juízes apontaram a necessidade de uma interpretação uniforme, além de atribuir à violência doméstica contra a mulher caráter de situação excepcional compatível ao objetivo do texto da Convenção ${ }^{97}$.

\footnotetext{
${ }^{93}$ Walsh vs. Walsh, 221 F.3d 204 (1st Cir. 2000) apud MORLEY, Jeremy. Op. Cit., p. 188.

${ }^{94}$ Tsarbopoulos vs. Tsarbopoulos, 176 F. Supp. 2d 1045 (E.D. Pa. 2010), In MORLEY, Jeremy D. The future of the grave risk of harm defense in Hague International Child Abduction Cases. International Family Law, New York, 2015. Disponível em: <www.international-divorce.com>. Acesso em: 21 out. 2015.

${ }^{95}$ Elyashiv vs. Elyashiv, 353 F. Supp. 2d 394 (E.D.N.Y. 2005); e Olhuin vs. Del Carmen Cruz Santana, 2005 U.S. Dist. Lexis, 408 (E.D.N.Y. 2005) In MAZZUOLI, Valério de Oliveira, Idem.

${ }^{96}$ Simcox vs. Simcox, 511 F.3d 594 (6th Cir. 2007); Van De Sande v. Van De Sande, 431 F3d 567 (7th Cir. 2005); Mltiadous v. Terervak, 686 F. Supp. 2d 544 (E.D Pa. 2010) Disponível em: <www.international-divorce.com>. Acesso em: 22 out. 2015.

${ }^{97}$ A doutrina americana vem caminhando neste mesmo sentido. Os professores Sudha Shetty e Jeffrey L. Edleson afirmaram em seu artigo o argumento de que "as the weight of the emerging social science evidence and U.S. public policy change brings about expanded definitions of a child's best interest, so too must there be an interpretation of the Hague Convention that prevents a battered mother from being compelled to return her children to an abusive father in a country which did not protect her or her children."

SHETTY, S. \& EDLESON, J.L. "Adult domestic violence in cases of international parental child abduction," Violence Against Women, 11, 2005, p. 115 - 138.
} 
A Suíça, por sua vez, introduziu o entendimento abrangente das expressões do artigo na sua legislação interna, de âmbito federal, cuja vigência se iniciou em 2009. A lei confere diretrizes acerca de como os tribunais nacionais devem interpretar a expressão "situação intolerável", além de designar representantes às crianças alvo de casos envolvendo a Convenção de Haia de 1980, como método de atender o melhor interesse da criança $^{98}$.

Isso comprova a vontade de muitos dos países em aprimorar as matrizes existentes na Convenção, em suprir as lacunas existentes a luz de seus princípios norteadores.

Além destas jurisprudências, atentemo-nos para outros cantos do mundo, que seguem no mesmo sentido:

\begin{abstract}
"Pesquisas realizadas em países como Grécia, Itália, Austrália, entre outros, envolvendo casos de sequestro internacional de crianças, também mostram que a violência doméstica aparece como motivo relevante para a fuga das mães levando seus filhos para outros países. Esses estudos indicam que as mulheres que sofrem violência fogem para outro país em busca da proteção que não obtiveram no país de residência habitual e que medidas legais precisam ser tomadas no sentido de tornar eficaz essa proteção no país para onde elas se deslocaram. Alguns autores, inclusive, recomendam que se criem novas leis internas, identificando claramente a exposição da criança a situações de violência doméstica como fator de "grave risco de dano físico e psicológico". Outra medida que também vem sendo proposta é a identificação do país de residência habitual da criança como sendo aquele que é capaz de oferecer proteção e garantir o seu efetivo bem-estar ${ }^{99,}$
\end{abstract}

No Brasil, temos poucas decisões que convolam a noção restrita dos conceitos chave do artigo 13, alínea b. O Tribunal Regional Federal da $2^{\mathrm{a}}$ Região decidiu no sentido de que a exceção "deve ser interpretada restritivamente, sendo necessário evitar a devolução de infantes a famílias desestabilizadas, a ambientes sociais ou nacionais perigosos" $" 100$.

Em outro caso semelhante, em sede de apelação, o mesmo tribunal entendeu que as exceções contidas no Artigo 13 e 20 deveriam ser

\footnotetext{
${ }^{98}$ MAZZUOLI, p. 247.

${ }^{99}$ Ibid., p. 246

${ }^{100}$ Ver nota de rodapé $n^{\circ} 67$.
} 
interpretadas restritivamente, pois o contrário faria com que a Convenção se tornasse letra morta e de que houvesse um estímulo à remoção ilícita, sob a ótica da transferência da competência jurisdicional para o país o sequestrador $^{101}$.

O que se têm visto são processos lentos, sem jurisprudência consolidada, casos em que devido à demora do processo a criança já se encontra adaptada ao novo meio ${ }^{102}$ e seu retorno poderia resultar em conturbações psicológicas para si.

\footnotetext{
${ }^{101}$ Ementa: INTERNACIONAL. REMOÇÃO ILÍCITA DE MENOR. CONVENÇÃO DA HAIA. MÉRITO DA GUARDA. IMPERTINÊNCIA. INTERESSE DA CRIANÇA. 1. Dos termos do art. $7^{\circ}$, letra f, da Convenção sobre os Aspectos Civis do Seqüestro Internacional de Crianças (Haia, 25.10.1980), promulgada pelo Decreto $\mathrm{n}^{\mathrm{o}} 3.413$, de 14.04.2000, depreendem-se a legitimidade ativa ad causam e o interesse processual da União, porquanto foi designada, no Brasil, como autoridade central a Secretaria de Estado dos Direitos Humanos do Ministério da Justiça. Demais, o pai do menor ingressou no processo como litisconsorte ativo superveniente, tanto quanto basta para justificar o exame do meritum causae. (...) 5. As exceções à regra da devolução da criança (artigos 13 e 20) devem ser interpretadas restritivamente, sob pena de a Convenção se tornar letra morta e admitir-se o estímulo à remoção ilícita, na medida em que a divergência entre os pais seria transferida ilegalmente para apreciação na jurisdição à qual a criança foi seqüestrada, provavelmente o país do seqüestrador. Como ensina Jacob Dolinger, as exceções devem ser entendidas em caráter humanitário, visando a evitar que a criança seja enviada a uma família perigosa ou abusiva, a um ambiente social ou nacional perigoso, como um país em plena convulsão. 6. Como decidiu a Suprema Corte da Argentina, "o objetivo da Convenção da Haia é precisamente procurar o melhor interesse da criança (Convenção dos Direitos da Criança), dando fim ao deslocamento ou à manutenção ilícita. 7. A Convenção da Haia atende perfeitamente não apenas aos direitos "à liberdade e à convivência familiar e comunitária" do menor - que não se reduzem, por óbvio, à família e comunidade do seqüestrador -, assegurados na Constituição da República (art. 227), como também ao direito de ser a criança cuidada pelos pais e de preservar sua identidade, inclusive a nacionalidade, o nome e as relações familiares, de acordo com a lei, sem interferências ilícitas, como asseguram os artigos $7^{\circ}$ e $8^{\circ}$ da Convenção da ONU sobre os Direitos da Criança. 8. Apelação improvida. AC 200551010097929 RJ 2005.51.01.009792-9 Desembargador Federal LUIZ PAULO S ARAUJO Fo/no afast. Relator. DJU - Data: 23/10/2007 Página:287/288.

${ }^{102}$ Ementa: CIVIL E INTERNACIONAL. CONVENÇÃO DA HAIA SOBRE ASPECTOS CIVIS DO SEQUESTRO INTERNACIONAL DE CRIANÇAS. BUSCA E APREENSÃO DE MENOR NASCIDA NA ARGENTINA. MÃE BRASILEIRA. ALEGADA RETENÇÃO ILÍCITA DA CRIANÇA NO BRASIL. MENOR EM TENRA IDADE. RESIDÊNCIA ESTABELECIDA EM COMPANHIA DA MÃE, A QUAL DETÉM SUA GUARDA PROVISÓRIA DEFERIDA POR AUTORIDADE JUDICIÁRIA NACIONAL. ADAPTAÇÃO AO DOMICÍLIO BRASILEIRO. SITUAÇÃO FAMILIAR ESTÁVEL FAVORÁVEL À MENOR NO TERRITÓRIO NACIONAL. RESTITUIÇÃO. NÃO RECOMENDÁVEL. FALTA DE DEMONSTRAÇÃO DE A MÃE TER AGIDO COM TORPEZA. PROVIMENTO DA APELAÇÃO DA RÉ. PREJUDICADO O RECURDO ADESIVO DA UNIÃO.

3. À luz do art. 12 da Convenção, desaconselhável a restituição "quando for provado que a criança já se encontra integrada no seu novo meio".

4. Diante da constatação no estudo psicológico de que a menor se encontra inteiramente integrada ao meio em que vive e que a mudança de domicílio poderá causar malefícios no seu futuro desenvolvimento -, e do próprio reconhecimento da Autoridade Central Administrativa de que "não seria prudente, portanto, arriscar que ela vivencie uma nova 'ruptura' de vínculos afetivos, especialmente em virtude de sua tenra idade" (três anos à época da avaliação) -, a "interpretação
} 
Porém, como visto no tópico anterior, o avanço nas questões de violência doméstica pelo nosso sistema interno vem como destaque a esse tipo de análise. Cerca de $90 \%$ dos casos que chegam ao Brasil envolvem alegações de violência domésticas contra a mulher, situações essas que vem tomando protagonismos pelos organismos responsáveis.

restritiva" dada pelo ilustre Juiz ao art. $\underline{12}$ da Convenção, determinando o imediato regresso à Argentina, quatro anos depois do seu ingresso em solo nacional (hoje conta com seis anos), vai de encontro à finalidade principal da Convenção, que é a proteção do interesse da criança.

5. Decidiu o STJ em caso parecido: "Dessa forma, quando for provado, como o foi neste processo, que a criança já se encontra integrada no seu novo meio, a autoridade judicial ou administrativa respectiva não deve ordenar o retorno da criança (art. 12), bem assim, se existir risco de a criança, em seu retorno, ficar sujeita a danos de ordem psíquica (art. 13, alínea b), como concluiu restar provado o acórdão recorrido, tudo isso tomando na mais alta consideração o interesse maior da criança" (REsp 900.262/RJ, Rel. Ministra Nancy Andrighi, Terceira Turma, DJ de 08/11/2007) 


\section{CONCLUSÃO}

Nosso mundo não hesita em se transformar. As sociedades do século XXI têm primado pelo dinamismo. As relações afetivas, pluralizaram-se. Os ordenamentos jurídicos rastejam em acompanhar a evolução das famílias. Transição de mulheres, homens, de coisas, de gente. $\mathrm{O}$ direito transbordou as barreiras das nações, e o povo, miscigenou.

Não só novas conjunturas, como também novos problemas surgiram. De montes, destacamos o papel do direito internacional na situação dos menores inseridos em famílias plurinacionais que se desintegram, se apartam, quando são retirados do convívio habitual de amigos e parentes para serem levados a outro país, tornando-se estranhos a seu próprio meio.

A Convenção de Haia de 1980 sobre sequestro internacional de menores obviamente transformou-se em um instrumento de suma importância para a proteção de crianças abduzidas, adotando regras e procedimentos avançados na busca pelo melhor interesse do menor.

Por meio do estudo de sua conjuntura, neste trabalho, não só identificamos o valor que o instrumento dá à manutenção do status quo, como também da inevitabilidade de modificação na seara jurídica para o cumprimento efetivo de suas máximas.

A relevância do sistema de cooperação jurídica (auxilio direto) por meio da criação das Autoridades Centrais - que no Brasil o protagonismo se dá na Secretaria de Direitos Humanos da Presidência da República - é um exemplo das evoluções pretendidas com o espraiamento dos princípios da Convenção. Um método balizador que proporcionou o acesso à justiça que muitos cidadãos que não detinham, facilitando que os casos fossem analisados e, por fim, solucionados. 
Apontamos conjuntamente o papel da mediação de conflitos como solução alternativa de dissolver a controvérsia familiar e proporcionar um elo de comunicação entre o genitor abdutor e o genitor abandonado.

A presença de um núcleo de solução de disputas como órgão componente do sistema judiciário é um primor, visto ser um instrumento capaz de harmonizar a relação entre as partes, além de garantir a continuidade do bom relacionamento pós resolução do conflito.

Vimos, também, que muitos de seus conceitos ainda travam batalhas entre os países-membros, desde a definição de "residência habitual" à discussão sobre competência para julgar a ação de retorno hoje já superada no Brasil.

No entanto, outros conceitos indeterminados causam polêmicas ainda maiores. É o que ocorre com os artigos 12, 13 e 20, que generalizam condições que configuram como restrições pautadas no melhor interesse do menor.

A Convenção não só determina regras ao procedimento de retorno como também estipula exceções a este quando configuradas situações de grave risco de ordem física, psicológica ou situação intolerável em que a criança possa se encontrar caso o retorno seja efetivado, dispostas nos artigos acima listados.

O artigo 13, alínea b, em específico, é o dispositivo que polemizou a estrutura da Convenção e dos próprios sistemas internos dos Estadosmembros em efetivá-la, por possuir os conceitos mais obscuros e subjetivos, desmembrando doutrinas e juízes.

Além disso, nos deparamos com uma "nova" problemática, que tomou espaço central na discussão: a violência doméstica. E esta discussão floresce enquanto há a insistência em interpretar a Convenção de forma limitada. As injustiças e a revitimização continuarão sem que haja uma 
análise mais profunda e atenta dos casos de sequestro, sob uma ótica mais permissiva e inclusiva.

É verdade que o indeterminismo e a falta de uniformidade nas decisões dos países membros geram inúmeras incertezas, até mesmo criadoras de insegurança jurídica, se não formos cautelosos. A confiança entre as nações é o cerne que sustenta o diálogo, porém, a existência de lacunas tão fortes pode alimentar sentimentos separatistas.

Fato é que sem a Convenção nos guiaríamos ao limbo, mas a partir da análise de jurisprudências estrangeiras e brasileiras percebe-se a necessidade imperiosa em reunir-se para rediscutir os conceitos e limitar as indeterminações antes que elas nos limitem.

A proposta, em conclusão, é o diálogo, a reforma, o aprimoramento tão imprescindível. A abertura interpretativa estudada e cuidadosa, e a inclusão dos procedimentos mais céleres e efetivos. Afinal, se almejamos a inclusão constante da Convenção de Haia de 1980 e do direito internacional nos conflitos de famílias, devemos evoluir todos em conjunto. 


\section{REFERÊNCIAS BIBLIOGRÁFICAS}

ARAUJO, Nádia de. Direito internacional privado: teoria e prática brasileira. Rio de Janeiro: Renovar, 2006

BASTOS LOPES, Rosanne Christine Da Silva. Seqüestro Internacional De Crianças: Análise e estudo do caso do menino Sean. Brasília: Repositório UNICEUB, 2010.

BRASIL. Lei n ${ }^{\circ} 11.340$, de 07/08/2006 (DOU 08/08/2006).

CARTILHA da Autoridade Central Administrativa do Brasil disponibilizada pela Secretaria de Direitos Humanos da Presidência da República. Disponível em: <http://www.sdh.gov.br/assuntos/adocao-esequestro-internacional/sequestro-internacional/arquivossubtracao/convencao-de-haia-de-1980>. Acesso em: 11 mai. 15.

CONVENÇÃO DE HAIA. Aspectos Civis do Sequestro Internacional de Crianças. 25 de Outubro de 1980. Disponível em: http://www.stf.jus.br/arquivo/cms/convencaoHaiaConteudoTextual/anexo/t extoConvencao.pdf > Acesso em 25 ago. 2015.

DE SOUSA, Mafalda Paulino Gomes. Convenção de Haia relativa ao rapto internacional de crianças: A noção de perigo do artigo 13 al. B) e o interesse da criança. Mestrado Forense. Faculdade de Direito da Universidade Católica Portuguesa. Lisboa, 2013.

DOLINGER, Jacob. Direito internacional privado: a criança no direito internacional. Rio de Janeiro: Renovar, 2003.

FILHO, Theophilo Antônio Miguel; ARAUJO, Nádia de. Questões constitucionais e legais da Convenção da Haia sobre os aspectos civis do sequestro internacional de crianças. Rio de Janeiro, 2010. Tese de Doutorado - Departamento de Direito, Pontifícia Universidade Católica do Rio de Janeiro.

GASPAR, Renata; AMARAL, Guilherme. Sequestro internacional de menores: os tribunais brasileiros têm oferecido proteção suficiente ao interesse superior do menor? Meritum, Belo Horizonte, v. 8 - n. 1, 2013, p. 351-387. 
INCADAT. Plataforma de jurisprudências estrangeiras nos casos da Convenção de Haia de 1980 sobre Sequestro Internacional de Menores. Disponível em: <http://www.incadat.com/index.cfm?act=analysis.show\&sl=3\&lng=1 $>$. Acesso em: 21 set. 2015.

MARTINS, Natalia Camba. Subtração Internacional de Crianças: as exceções à obrigação de retorno previstas na Convenção de Haia de 1980 sobre aspectos civis do sequestro internacional de crianças: interpretação judicial da adaptação da criança - 1. Ed. - Curitiba, PR: CRV, 2013.

. Curso sobre Sequestro Internacional de Crianças. Conferência 6: "Exceções à Obrigação de Retorno Imediato de Crianças Vítimas de Subtração Internacional (artigos 12, 13 e 20 da Convenção de Haia de 1980), em palestra no TRF da $4^{\text {a }}$ região sobre Sequestro Internacional de Menores. Disponível

em: $<$ http://www2.trf4.jus.br/trf4/controlador.php?acao=pagina_visualizar\&id_ pagina $=1220 \#$ MATERIAIS $>$. Acesso em: 5 mai. 15

MAZZUOLI, Valério de Oliveira. Curso de direito internacional público. 9. ed. rev., atual. e ampl. São Paulo: Ed. RT, 2015.

MAZZUOLI, Valério de Oliveira; MATTOS, Elsa de. Sequestro internacional de criança fundado em violência doméstica perpetrada no país de residência: a importância da perícia psicológica como garantia do melhor interesse da criança. Revista dos Tribunais, vol. 954 (2015), p. 239254.

MÉRIDA, Carolina Helena. Sequestro Interparental: Princípio da residência habitual. Revista de Direito Internacional, Brasília, v. 8, n. 2, p. 255-272, jul./dez. 2011. Disponível em: < http://www.publicacoesacademicas.uniceub.br/index.php/rdi/article/downlo ad/1544/1435>. Acesso em: 9 mai. 2015

MORE, Rodrigo F. A violência doméstica e familiar contra a Mulher e o sequestro internacional de crianças: Estudos de casos e medidas urgentes. Revista Estudos Jurídicos UNESP, Franca, A. 14 n.20, 2010.

MORLEY, Jeremy D. The future of the grave risk of harm defense in Hague International Child Abduction Cases. International Family Law, New York, 2015. Disponível em: <www.international-divorce.com>. Acesso em: 21 out. 2015. 
. The Hague Abduction Convention: practical issues and procedures for Family lawyers, Chicago, IL: ABA (American Bar Association), 2012.

PELED, Einat; DAVIS, Diane. Groupwork with children of battered women: a practioner's guide. California: Sage Publications, 1995.

PEREZ-VERA, Elisa. Explanatory Report: Hague Conference on Private International Law. Acts and Documents of the Fourteenth Session (Child Abduction), vol. 3 (1980), p. 426 ss.

RAMOS, André de Carvalho. Artigo Pluralidade Das Ordens Jurídicas: Uma Nova Perspectiva Na Relação Entre O Direito Internacional E O Direito Constitucional, em Revista da Faculdade de Direito da Universidade de São Paulo, v. 106/107.

SHETTY, Sudha; EDLESON, Jefferson L. Adult domestic violence in cases of international parental child abduction. Violence Against Women, n. 11 (2005), p. 115-138.

SIFUENTES, Monica. Sequestro Interparental: a experiência brasileira na aplicação da Convenção de Haia de 1980. Revista da Seção Judiciária do Rio de Janeiro (SJRJ), Rio de Janeiro, n. 25, p. 135-144, 2009. Disponível em: $\quad<$ http://www.sdh.gov.br/assuntos/adocao-e-sequestrointernacional/legislacao-e-publicacoes/sequestro-interparental-aexperiencia-brasileira-na-aplicacao-da-convencao-de-haia-de-1980>. Acesso em: 15 mai. 2015.

STJ, $2^{\text {a }}$ Seção, CC 100.345, Relator Min. Luis Felipe Salomão, 18 mar.2009.

TRF $2^{\mathrm{a}}$ Região, $8^{\mathrm{a}}$ Turma Especializada, MS 2009.02.01.004118-6, Relator Desembargador Federal Raldenio Bonifacio, 28 jul. 2009.

TRF $3^{\mathrm{a}}$ Região, $2^{\mathrm{a}}$ Turma, AC 0001923-25.2008.4.03.6123/SP, Relatora Desembargadora Federal Cecília Mello, 29 jun. 2010.

TRF 2a Região, 5 ${ }^{\mathrm{a}}$ Turma Especializada, AC 2009.51.01.018422-0, Relator Desembargador Federal Fernando Marques, 16 dez. 2009.

TRF 2a Região, $8^{\mathrm{a}}$ Turma Especializada, AC 2004.50.01.005578-3, Relator Juiz Convocado Marcelo Pereira Da Silva, 04 ago. 2009.

TIBURCIO, Carmen. Curso sobre Sequestro Internacional de Crianças. Convenção da haia sobre sequestro de menores: residência habitual, em 
palestra no TRF da $4^{\text {a }}$ região sobre Sequestro Internacional de Menores. Disponível em: <http://www2.trf4.jus.br/trf4/controlador.php?acao=pagina_visualizar\&id_ pagina $=1220 \#$ MATERIAIS $>$. Acesso em: 2 mai. 15.

TIBURCIO, Carmen; CALMON, Gulherme. Sequestro Internacional de Menores: comentários à Convenção de Haia de 1980, São Paulo: Atlas, 2014

WEINER, Merle H. Navigating the road between uniformity and progress: the need for purposive analysis of the Hague Convention on the Civil Aspects of International Child Abduction. Columbia Human Rights Law Review, vol. 33 (2002), p. 275-279. 